\title{
1 A horizontally acquired expansin gene increases virulence of the emerging plant \\ 2 pathogen Erwinia tracheiphila
}

3 Jorge Rocha ${ }^{\mathrm{a}, \mathrm{b} * \# \text {, Lori R. Shapiro }}{ }^{\mathrm{a}, \mathrm{c} *}$, Roberto Kolter ${ }^{\mathrm{a}}$

4

$5 \quad$ \#Address correspondence to Jorge Rocha, jorge.rocha@ciad.mx

$6 \quad{ }^{a}$ Department of Microbiology, Harvard Medical School, Boston MA.

$7 \quad$ b Present Address: Conacyt-Centro de Investigación y Desarrollo en Agrobiotecnología

8 Alimentaria, San Agustin Tlaxiaca, Mexico

$9{ }^{\mathrm{c}}$ Present Address: Department of Applied Ecology, North Carolina State University,

10 Raleigh, NC

11

$12 *$ JR and LRS contributed equally to this work.

13 Word count: Abstract 219, Main Text (Introduction, Results, Discussion) 4354

15 Running title: An expansin increases Erwinia tracheiphila virulence

16 \#Address correspondence to Jorge Rocha, jorge.rocha@ciad.mx

17 Keywords: expansin, virulence, glycoside hydrolase, Cucurbita, Erwinia, squash, plant

18 cell wall, cellulose, pectin, horizontal gene transfer, plant pathogen, xylem

20 Author Contributions: JR and LRS conceived of the study. JR designed and conducted

21 molecular protocols and lab experiments. LRS conducted computational analyses and

22 performed experiments. JR, LRS and RK interpreted experimental data. JR and LRS

23 wrote the first draft of the manuscript, and JR, LRS and RK added critical revisions. 
bioRxiv preprint doi: https://doi.org/10.1101/681643; this version posted July 2, 2019. The copyright holder for this preprint (which was not certified by peer review) is the author/funder, who has granted bioRxiv a license to display the preprint in perpetuity. It is made available under aCC-BY-NC-ND 4.0 International license.

24

25 Data Deposition Statement: Analysis scripts and input files associated with

26 reconstruction of phylogenetic trees are available at

27 https://github.com/lshapiro31/gh5.expansin.phylogenetics 


\section{Abstract}

29 All land plants depend on proteins called 'expansins' that non-enzymatically loosen structural

30 cellulose, enabling cell wall extension during normal growth. Surprisingly, expansin genes are

31 also present - but functionally uncharacterized - in taxonomically diverse bacteria and fungi that

32 do not produce cellulosic cell walls. Here, we find that Erwinia tracheiphila

33 (Enterobacteriaceae), the causative agent of bacterial wilt of cucurbits, has horizontally acquired

34 an operon with a microbial expansin $(e x l x)$ gene and a glycoside hydrolase family 5 (gh5) gene.

35 E. tracheiphila is an unusually virulent plant pathogen that induces systemic wilt symptoms

36 followed by plant death, and has only recently emerged into cultivated cucurbit populations in

37 temperate Eastern North America. Plant inoculation experiments with deletion mutants show that

38 EXLX-GH5 is a secreted virulence factor that confers efficient xylem movement and

39 colonization ability to E. tracheiphila. Bacterial colonization of xylem blocks sap flow, inducing

40 wilt symptoms and causing plant death. Together, these results suggest that the horizontal

41 acquisition of the exlx-gh5 locus was likely a key step driving the recent emergence of $E$.

42 tracheiphila. The increase in E. tracheiphila virulence conferred by microbial expansins, the

43 presence of this gene in many other bacterial and fungal wilt-inducing plant pathogen species,

44 and the amenability of microbial expansins to horizontal gene transfer suggest this gene may be

45 an under-appreciated virulence factor in taxonomically diverse agricultural pathogens. 


\section{Importance}

Erwinia tracheiphila is a bacterial plant pathogen that causes a fatal wilt infection in cucurbit

crop plants. Here, we report that E. tracheiphila has horizontally acquired a microbial expansin gene (exlx) adjacent to a glycoside hydrolase family 5 (gh5) gene. Expansins are predominantly associated with plants due to their essential role in loosening structural cell wall cellulose during normal growth. We find that the EXLX and GH5 proteins in E. tracheiphila function as a single complex to facilitate xylem colonization, possibly by manipulating the size of xylem structures that normally exclude the passage of bacteria. This suggests that horizontal acquisition of the exlx-gh5 locus was likely a key step in the recent emergence of E. tracheiphila as an unusually virulent plant pathogen. The presence of microbial expansin genes in diverse species of bacterial and fungal wilt-inducing pathogens suggests it may be an under-appreciated virulence factor for other microbes.

\section{Introduction}

61 The surfaces of all land plants are colonized by complex microbial communities. For a microbe, the ability to colonize a plant increases access to the nutritional resources produced by that plant (1-3). This has driven the evolution of diverse molecular mechanisms for plant colonization that can be found in commensal, beneficial and pathogenic microbes (4-6). A group of particularly intriguing, yet largely uncharacterized genes identified in an increasing number of plantassociated bacterial and fungal species encode proteins called 'expansins' (7-10). Expansins are non-enzymatic, two-domain proteins of $\sim 250$ amino acids; the $\mathrm{N}$-terminal domain is related to 
green algae, where they fulfill the essential role of non-enzymatically loosening cell wall cellulose during normal growth of any rapidly expanding tissues $(11,14-18)$. In bacteria and fungi - which do not have cellulosic cell walls - expansin genes are variably present in species that interact with live or dead plant or algal matter $(7,8,10,19)$. The function(s) of expansins in microbes are unknown for almost all species, but are thought to promote colonization of plants through interactions with plant cell wall cellulose $(7,8,20)$.

In the few microbial species where expansin functions have been empirically investigated, their contributions to plant colonization have been diverse. The microbial expansin in the plant commensal Bacillus subtilis (BsEXLX1) has only a fraction of the in vitro ability to extend plant cell walls compared to plant expansins, but BsEXLX1 deletion mutants are either severely impaired, or unable to successfully colonize the surface of maize roots $(20,21)$. In some species of plant beneficial fungi, expansins (also referred to as 'swollenins') increase fungal mutualistic capabilities towards plant hosts $(22,23)$. Expansin function has also been investigated in several pathogens. In the bacterial plant pathogen Ralstonia solanacearum, an expansin deletion mutant has decreased virulence (24), and in Clavibacter michiganensis, studies have described contradictory expansin roles for virulence and ability to colonize xylem (24-28). Overall, fundamental questions surrounding how microbial expansins mediate plant colonization in divergent genetic backgrounds and variable ecological contexts, and the molecular mechanism(s) by which microbial expansins interact with plant structural carbohydrates remain enigmatic $(7,8,10,19,20,24,26,29,30)$.

The bacterial plant pathogen Erwinia tracheiphila Smith (Enterobacteriaceae), the causative agent of bacterial wilt of cucurbits, contains an operon with an expansin gene (exlx) and a gene fragment with a glycoside hydrolase family 5 functional domain $(g h 5)(8,31-33)$. The 
only geographic region where E. tracheiphila occurs is temperate Eastern North America, and it

only infects species in two genera of cucurbit host plants: summer and winter squash (cultivars

E. tracheiphila genome has undergone dramatic structural changes consistent with an

evolutionarily recent emergence, including the horizontal acquisition of multiple genes likely

important for virulence (34-38). Unlike most bacterial plant pathogens, E. tracheiphila cannot

persist in environmental reservoirs, and instead is only transmitted by two species of highly

specialized leaf beetle vectors (39-42). Bacterial cells can enter xylem when beetle frass

$102(40,43)$. Bacterica can then move systemically through xylem and block sap flow to induce

107 empirically assessed.

110 the exlx and gh5 open reading frames (ORFs), and find that the phylogenies of both exlx and gh5

111 are consistent with horizontal acquisition by E. tracheiphila. Then, we create deletion mutants to

112 determine the individual and combined roles of exlx and gh5 for E. tracheiphila colonization of

113 host plants. In planta inoculation experiments with the wild type and mutant strains show that

114 these proteins are secreted, and suggest that they function as a single assembled EXLX-GH5

115 complex. The EXLX-GH5 protein complex is necessary for E. tracheiphila to efficiently 
116 colonize xylem, induce systemic wilt symptoms, and cause high rates of plant death. Together,

117 these results suggest that the exlx-gh5 locus as a non-canonical yet potent virulence factor, and

118 horizontal acquisition of this locus was a key event driving the recent emergence of $E$.

119 tracheiphila as a fatal plant pathogen that can efficiently colonize xylem. These findings

120 highlight the continued risk of horizontal gene transfer driving an increase in pathogen virulence,

121 and the continuing vulnerability of agricultural populations to invasion by pathogen variants or

122 species with increased virulence.

Results

125 Identification of a locus with an expansin gene in Erwinia tracheiphila

126 A locus with two open reading frames (ORFs) flanked by mobile DNA elements was identified

127 during manual curation of ab initio gene predictions in the Erwinia tracheiphila reference strains

$128(31,32)$ (Figure 1A). The first ORF, Et-exlx (AXF78871.1), is predicted to encode a protein

129 product with 243 amino acids and both domains found in canonical expansin proteins $(17,47)$.

130 The second ORF, Et-gh5 (AXF77819.1), has 315 codons and is predicted to encode a putatively

131 pseudogenized endo-1,4-beta-xylanase A precursor (EC 3.2.1.8) with a glycoside hydrolase

132 family 5 (GH5) functional domain (www.CAZy.org) (48). Many Et-gh5 homologs in the NCBI

$133 n r$ database are between 415 - 450 amino acids, and RAST ab initio gene annotation predicts

134 that the truncation to 315 amino acids eliminates cellulase activity and renders Et-gh5 non-

135 enzymatic (49). The sequences of both ORFs predict a signal peptide for secretion and a Signal

136 Peptidase cleavage site (50), suggesting that the protein products are secreted and their function

137 is extracellular. 
Phylogenetic distribution of the Erwinia tracheiphila expansin and gylocoside hydrolase family 5

140 open reading frames

141 Because mobile DNA elements are common agents of horizontal gene transfer, the phylogenies

142 of both the exlx and gh5 genes were reconstructed and evaluated for conflict with the species

143 phylogeny $(37,51-53)$. Homologs of both genes are only found in species that interact with live

144 plants, or soil-dwelling species that likely interact with dead plant matter. The $\gamma$-proteobacterial

145 expansin homologs are recovered as two distinct groups, separated by Firmicutes (Figure 1B).

146 The expansin homologs in the Enterobacterial plant pathogens (Pectobacterium spp., Dickeya

147 spp., Pantoea stewartii and E. tracheiphila) comprise one group, and the expansin homologs

148 from Xanthomonadaceae comprise a second group (8). Erwinia tracheiphila and Pantoea

149 stewartii are the only species with microbial expansin homologs from the Erwinia and Pantoea

150 genera, respectively. This suggests that an expansin gene was horizontally acquired by an

151 ancestral plant-associated Enterobacteriaceae species, and this original acquisition was followed

152 by vertical and horizontal transmission between other plant-associated Enterobacteriaceae (8).

153 The expansin phylogeny is consistent with additional horizontal gene transfer events, such as an

154 expansin acquisition by the $\beta$-proteobacterial plant pathogen Ralstonia solancearum from a

155 Xanthomonadaceae donor $(8,10)$.

$156 \quad$ Gh5 homologs have a relatively sparse distribution in bacteria and some plant pathogenic

157 nematodes, and the gh5 phylogeny is also consistent with multiple horizontal gene transfer

158 events (Figure 1C). Gh5 homologs are present in the genomes of Enterobacteriaceae, Firmicutes,

159 Myxobacteria and $\beta$-proteobacteria that also have expansin genes. Homologs are also present in

160 species of Bacteroidetes and $\gamma$-proteobacteria species that do not have expansin genes. In

161 Enterobacteriaceae, the gh5 homologs separate into three distinct groups. One group is 
162

163

164

165

166

167

168

169

170 181 gene transfer.

Many plant pathogenic Xanthomonadaceae have a gh5 domain fused to an exlx as a

183 single ORF $(8,55)$. The gh5 domain in Enterobacteriaceae is non-homologous to the GH5

comprised of Erwinia tracheiphila, Pantoea stewartii, Dickeya dianthicola, and Phaseolibacter

sp. (recently reclassified to Enterobacteriaceae (54)). The other plant-pathogenic Dickeya spp.

comprise a second group of Enterobacterial gh5 homologs, and plant-pathogenic Pectobacterium and Brennaria spp. are a third group.

Distribution of expansin fusions to carbohydrate active domains in bacteria

In approximately $10 \%$ of microbial species, expansin genes are fused to domains from carbohydrate active proteins $(8,10)$. Out of the hundreds of families of carbohydrate active domains in the CAZy database (www.cazy.org), only GH5 and carbohydrate binding module family 2 (CBM2) domains repeatedly co-occur with bacterial expansin genes $(8,48)$. Bacterial species that have an expansin co-occurring with a carbohydrate active domain are more likely to be xylem-colonizing pathogens (8). The co-occurrence of GH5 domains with expansins in bacterial plant pathogens is especially apparent (Figure 2).

A gh5 homolog is present in the genomes of multiple plant-pathogenic Pectobacterium and Dickeya species that harbor an exlx homolog (Figure 1B, 1C). However, only three enterobacterial species (Erwinia tracheiphila, Pantoea stewartii, and Dickeya dianthicola) have the exlx and gh5 ORFs in the same operon. In these three species, the exlx and gh5 genes have distinct signal peptides and are separated by $\sim 50$ nucleotides. In $P$. stewartii, the exlx-gh5 locus is on a plasmid (pDSJ08), which may increase the probability of acting as a donor for horizontal

$$
\text { domain in Xanthomonadaceae, and the exlx and gh5 domain structure in some }
$$


185 Enterobacteriaceae is in reverse orientation compared to the gh5-exlx domain order in

186 Xanthomonadaceae. A distinct gh5 domain that is truncated to 289 amino acids is found in

187 Clavibacter michiganensis (CelA), and this is the only known microbial expansin that is fused to

188 both a GH5 and CBM2 domain in a single coding sequence (27). This suggests there have been

189 at least three independent origins of an expansin adjacent or fused to a gh5 family functional

190 domain in bacterial plant pathogens. These multiple independent co-occurrences of bacterial

191 expansins with evolutionarily distinct $g h 5$ domains may be an example of functional

192 convergence.

194 Expansin and GH5 genes both contribute to Erwinia tracheiphila virulence

195 The functional significance of a microbial expansin co-occuring with a carbohydrate

196 active domain has not yet been empirically tested. To evaluate the role of EXLX and GH5 to $E$.

197 tracheiphila virulence - and the possible synergistic effects of both proteins together - we

198 generated a deletion mutant of the complete operon (strain $\Delta e x l x-g h 5)$, and mutants in only the

199 expansin ORF (strain $\Delta e x l x$ ) and only the GH5 ORF (strain $\Delta g h 5$ ). Strains that complemented

200 the three deletion mutations ( $\Delta e x l x-g h 5(\mathrm{cEXLX}-\mathrm{GH} 5), \Delta \operatorname{exlx}(\mathrm{cEXLX})$ and $\Delta g h 5(\mathrm{cEXLX}-\mathrm{GH} 5)$,

201 respectively) were also constructed (Supplemental Table 1). Variation in virulence between the

202 wild type (Wt), mutants and complemented strains were measured via squash seedling

203 inoculation experiments. Virulence was compared by quantifying differences in the amount of

204 time it took each strain to induce disease symptoms at three stages: 1) at initial wilt symptom

205 development on the inoculated leaf, 2) at systemic spread of wilt symptoms to a second non-

206 inoculated leaf, and 3) at plant death. 
In plants inoculated with $\Delta e x l x-g h 5$, wilt symptoms were delayed in the inoculated leaf and in a second systemic leaf, and significantly fewer plants inoculated with $\Delta$ exlx-gh5 died $(23 \% ; 5$ of 22$)$ compared to plants inoculated with $\mathrm{Wt}(85 \% ; 17$ out of 20) (Figure 3A, Tables 1 and 2). Wilt symptoms in plants inoculated with $\Delta$ exlx-gh5 were more likely to be localized to

211 the inoculated leaf (i.e., symptoms did not progress to systemic infection or plant death)

212 compared to plants inoculated with Wt (Figure 4). The $\Delta$ exlx-gh5(cEXLX-GH5) complemented

213 strain had restored ability to induce wilting symptoms at a second non-inoculated leaf, and

214 partially restored the mortality rate $(60 \% ; 13$ out of 22$)$.

216 compared to Wt (Figure 3, Tables 1-4). Plants inoculated with either $\Delta$ exlx or $\Delta g h 5$ exhibited delays in the initial appearance of wilt symptoms in the inoculated leaf, delays in the appearance

218 of systemic wilt symptoms in a second leaf and decreased mortality compared to Wt. Genetic

219 complementation of $\Delta \operatorname{exl} x$ in strain $\Delta \operatorname{exlx}(\mathrm{cEXLX})$ did not restore the Wt ability to cause wilt

220 symptoms in the inoculated leaf, but did restore the ability to cause systemic wilt symptoms and 221 plant death (Figure 3A, Tables 1 and 2).

Promoter regions for expression of the exlx-gh5 operon have not been characterized, but expression of individual ORFs in an operon is often directed from an upstream shared promoter.

224 It is therefore reasonable to assume expression of the gh5 ORF is directed from a shared

225 promoter region upstream of $\operatorname{exlx}(56)$. For this reason, the single $\Delta g h 5$ mutant was

226 complemented with the full operon (exlx-eng) to include the promoter region of exlx.

227 Complementation of $\Delta g h 5$ with $\Delta e x l x$-gh5(EXLX-GH5) restored the Wt ability to cause wilt 228 symptoms in the inoculated leaf, systemic wilt symptoms in a second leaf, and plant death 229 (Figure 3B Tables 3 and 4). 
The Aexlx-gh5 mutant is impaired in systemic movement

232 The correlation between within-plant movement of E. tracheiphila to systemic wilt symptom

233 development and plant death has been hypothesized, but not yet demonstrated $(34,57)$. It is

234 assumed that systemic movement of bacteria through xylem - along with bacterial replication

235 and increase in biomass far from the initial inoculation point - is necessary to occlude xylem

236 vessels to cause wilt symptoms and plant death (Figure 4) $(34,57)$. To explicitly test whether

237 Aexlx-gh5 has impaired within-host movement, squash seedlings were inoculated with either $\mathrm{Wt}$

238 or $\Delta e x l x$-gh5. At $12 \mathrm{DPI}$, bacteria were quantified at two sites in the same plant: the petiole of the

239 inoculated leaf, and the petiole of a second, non-inoculated leaf. At 12 DPI, all of the plants

240 inoculated with the Wt strain were systemically wilting, but none of the plants inoculated with

$241 \Delta$ Aexlx-gh5 had wilt symptoms beyond the inoculated leaf. At the inoculation site of all plants, the

$242 \mathrm{Wt}$ and $\Delta$ exlx-gh5 both reached similar cell counts $\left(>10^{9} \mathrm{CFU} / \mathrm{g}\right.$ for $\mathrm{Wt}$, and $10^{8}-10^{9} \mathrm{CFU} / \mathrm{g}$ for

$243 \Delta e x l x-g h 5)$ (Figure 5). However, in a petiole of a second, non-inoculated leaf $\Delta e x l x$-gh5 only

244 reached cell counts of $10^{3} \mathrm{CFU} / \mathrm{g}$, while the $\mathrm{Wt}$ reached $10^{9} \mathrm{CFU} / \mathrm{g}$ (Figure 5). The $\Delta e x l x$-gh5

245 strain does not have a growth deficiency in vitro compared to the Wt (Supplemental Figure 1),

246 showing that the attenuation of wilt symptom development and decrease in plant death rates

247 (Figures 3 and 4) is due to impaired systemic movement of $\Delta e x l x-g h 5$ and not a difference in 248 growth rate per se.

250 Systemic wilt symptoms are correlated with local Erwinia tracheiphila concentration

251 A second inoculation experiment using only the $\Delta$ exlx-gh5 mutant was conducted to quantify

252 how wilt symptom severity is correlated with the ability of E. tracheiphila to move through, and 
replicate in xylem beyond the inoculation point. Thirty plants were inoculated with $\Delta e x l x-g h 5$,

and after 21 days symptoms in each plant were scored as either no symptom in any leaf

(healthy), wilt symptoms restricted to the site of inoculation, systemic wilt symptoms beyond the

inoculated leaf, or death. Bacteria were then quantified with CFU counts from the petiole of the

inoculated leaf and a petiole of a second non-inoculated leaf.

At 21 DPI, 8 plants were healthy and had not developed any wilt symptoms, 12 only had

(Figure 6). In the petiole of the inoculated leaf, the bacterial concentration reached $\sim 10^{8}$ to $10^{9}$

$\mathrm{CFU} / \mathrm{g}$ in 26 out of the 30 experimental plants regardless of symptom severity. Cell counts from

262 the inoculation site were lower (below $<10^{7} \mathrm{CFU} / \mathrm{g}$ ) in the remaining 4 plants, three of which

263 were healthy and one that had symptoms only in the inoculated leaf (Figure 6). In the petiole of a

264 second non-inoculated leaf, bacterial concentration was correlated with overall severity of wilt

265 symptoms, with lower severity corresponding to lower bacterial numbers. In 6 of the 8 healthy

266 plants that did not develop any wilt symptoms, bacterial cells were undetectable at a non-

267 inoculated leaf, and bacterial cells in a second non-inoculated leaf of the remaining two healthy

268 plants were just barely over the $\sim 10^{3} \mathrm{CFU} / \mathrm{g}$ threshold of detection (Figure 6). In the 12 plants

269 that developed wilt symptoms only in the inoculated leaf, the bacterial numbers at a non-

270 inoculated leaf were highly variable (ranging from $10^{4}$ to $10^{8} \mathrm{CFU} / \mathrm{g}$ ). In 7 out of 10 systemically

271 wilting plants, the bacterial concentration recovered at a second non-inoculated leaf was similar

272 to the cell counts recovered at the local inoculation site $\left(\sim 10^{8} \mathrm{CFU} / \mathrm{g}\right)$. These results explicitly

273 correlate severity of wilt symptoms with the ability of E. tracheiphila to move systemically and

274 increase in population far from the initial inoculation site to block xylem sap flow (Figure 4). 
Erwinia tracheiphila does not have cellulase or xylanase activity

277 All expansin proteins (from plants, bacteria, fungi, or other microbial eukaryotes) do not have a

278 detectable enzymatic activity $(7,13,19,58)$. However, glycoside hydrolases are enzymes that

279 break the glycosidic bond between two or more carbohydrate subunits, and the predominant

280 target of these enzymes is cellulose (48). It is therefore possible that the gh5 ORF adjacent to or

281 fused to bacterial expansin genes in some species may confer enzymatic activity. To test whether

282 the gh5 ORF confers carbohydrate degrading ability to E. tracheiphila, the Wt strain (with the

283 intact exlx-gh5 locus) was evaluated for enzymatic degradation of cellulose and xylan, the two

284 main structural components of plant cell walls and the putative targets of active GH5 enzymes

285 (59). Neither E. tracheiphila culture supernatant nor colonies had detectable hydrolytic activity

286 against cellulose or xylan (Supplemental Figure 2). The absence of enzymatic activity is

287 consistent with previous results from both plant and microbial expansins where no enzymatic

288 activity has ever been detected $(7,13,19)$.

Neither flagella nor Type IV Pili contribute to Erwinia tracheiphila systemic xylem colonization

Type IV Pili and flagella are used by some bacterial plant pathogens during systemic

292 movement through xylem (60-63). To assess whether these cellular components may also

293 contribute to E. tracheiphila xylem colonization, deletion mutants were generated for Type IV

294 Pili $(\triangle T 4 P)$ and flagella $(\triangle f l i C)$ (Supplemental Table 1). In squash inoculation experiments, the

295 virulence phenotypes of $\Delta T 4 P$ and $\Delta f l i C$ mutants were indistinguishable from Wt. There was no

296 difference in the development of wilt symptoms or death rate from inoculation with either $\triangle T 4 P$,

$297 \Delta f l i C$, or Wt (Figure 7, Tables 5 and 6). This indicates that neither Type IV Pili nor flagellar 
movement contribute to xylem colonization by E. tracheiphila, although it is still possible that these loci contribute in other, more subtle, ways to pathogenesis.

The Et-exlx-gh5 protein is secreted during infection

302 To test whether the protein products of the Et-exlx-gh5 locus are secreted (as predicted by the

303 presence of signal peptides), plants were co-inoculated with a 1:1 mix of Wt \& $\Delta$ exlx-gh5.

304 Successful restoration of $\Delta$ exlx-gh5 colonization from in trans complementation by the Wt strain

305 would indicate that the EXLX and GH5 proteins provided by the Wt strain are secreted and

306 function extracellularly. An equal number of plants were inoculated with only the Wt or only the

307 Aexlx-gh5 mutant. In singly inoculated plants, the Wt or $\Delta$ exlx-GH5 reached the same

308 concentration in the inoculated site at $1 \mathrm{DPI}$, but only the Wt was detected in a petiole of a non-

309 inoculated leaf at 12 DPI (Figure 8A).

310 In co-inoculated plants, both Wt \& $\Delta$ exlx-gh5 strains were present at similar

311 concentrations at the inoculation site at 1 DPI (Figure 8B). After 12 days, two of the 4 plants co-

312 inoculated with the 1:1 mix of Wt \& $\Delta$ exlx-gh5 developed systemic wilt symptoms. In these two

313 co-inoculated plants, the cell count of Wt in the petiole of a non-inoculated leaf reached $10^{7}-10^{8}$

$314 \mathrm{CFU} / \mathrm{g}$, and the cell count of $\Delta$ exlx-gh5 reached $10^{5}-10^{6} \mathrm{CFU} / \mathrm{g}$ (Figure 8B). This is a notably

315 higher cell count than $\Delta \operatorname{exl} x$-gh5 reaches at the same 12 day time point when singly inoculated

$316\left(10^{3}-10^{4} \mathrm{CFU} / \mathrm{g}\right)$ (Figure 5, Figure $\left.8 \mathrm{~A}\right)$. The ability of the Wt to partially rescue the systemic

317 colonization defect of $\Delta$ exlx-gh5 in trans (when the Wt and $\Delta e x l x$-gh5 are co-inoculated)

318 indicates that EXLX and GH5 are secreted and function extracellularly.

319 To test whether the EXLX and GH5 proteins function independently or as a single

320 assembled unit, plants were co-inoculated with a 1:1 mix of $\Delta e x l x$ and $\Delta g h 5$. The $\Delta$ exlx deletion 
mutant is expected to still secrete an intact GH5 protein, and the $\Delta g h 5$ deletion mutant is

expected to still secrete an intact EXLX protein. If the EXLX and GH5 proteins function

323 independently, the two strains would complement each other in trans. However, co-inoculating

324 the $\Delta e x l x$ and $\Delta g h 5$ single deletion mutants did not rescue the attenuated virulence phenotype of

325 the individual deletion mutants (Figure 9, Tables 7 and 8). This indicates that these proteins

326 function as a single EXLX-GH5 protein complex that assembles before or during secretion, and

327 therefore both proteins must be produced by the same cell.

\section{Discussion}

Here, we find that the emerging plant pathogen Erwinia tracheiphila has horizontally

331 acquired an exlx-gh5 locus that functions as a virulence factor by conferring the ability to

332 systemically colonize xylem, block sap flow and cause high rates of plant death. The ability of a

333 pathogen to move systemically through host vasculature - either plant xylem or animal

334 cardiovascular systems - is a high-virulence phenotype, and is associated with development of

335 more severe symptoms than localized infections $(64,65)$. The ability of a pathogen to reach a

336 high titre and be distributed throughout the host's vasculature is also necessary for vector

337 transmission by providing more opportunities for acquisition $(64,66)$. In E. tracheiphila, the

338 development of systemic wilt symptoms induces a chemical volatile phenotype that attracts

339 significantly more foraging vectors to wilting leaves $(45,67)$, and a physical phenotype that

340 facilitates insect vector feeding - and increased pathogen acquisition opportunities - from

341 symptomatic foliage $(40,45)$. This increase in virulence conferred by the Et-exlx-gh5 locus

342 induces more severe symptoms in infected plants that both attract obligate insect vectors to

343 infected plants, and facilitates preferential feeding on wilting tissue once they arrive. Together, 
344 this suggests that the horizontal acquisition of the exlx-gh5 locus was a key step in the recent

345 emergence of E. tracheiphila as a virulent wilt-inducing pathogen that is obligately insect vector

346 transmitted $(34,37)$.

347 In $\sim 10 \%$ of bacterial species that have expansin genes, the expansin is fused to domains

348 from carbohydrate active proteins. The formation of new genes via fusions of multiple modular

349 domains is a key source of evolutionary innovation for organisms across the tree of life $(68,69)$.

350 Expansin co-occurrence with gh5 domains is over-represented in pathogenic bacterial species

351 that can move through xylem (8), suggesting there may be emergent properties of the EXLX-

352 GH5 protein complex that are uniquely adaptive for xylem-colonizing plant pathogenic bacteria.

353 Healthy plants have effective physical barriers to allow the flow of xylem sap while excluding

354 bacteria; pit membranes between adjacent tracheids and perforation plates between xylem

355 vessels are openings on a nanometric scale, while most bacteria are $\sim 1 \mu \mathrm{m}$ (70). One hypothesis

356 is that bacterial expansins may non-enzymatically 'loosen' the cellulose and pectin matrix at the

357 perforation plates or at the pit membranes in order to increase their size enough to allow the

358 passage of bacterial cells (71-74). The ability of E. tracheiphila Wt strain to complement $\Delta$ exlx-

359 gh5 in trans is consistent with the hypothesis that the EXLX-GH5 protein complex functions

360 extracellularly by interacting with xylem structrual carbohydrates that would normally prevent

361 bacterial passage. This also suggests that, while the Et-gh5 enzymatic activity has been lost due

362 to truncation, the remaining fragment may have been neofunctionalized and is providing an

363 essential (though mechanistically undefined) role in virulence. One possibility is that the gh5

364 functional domain may physically (but non-enzymatically) interact with plant structural

365 carbohydrates at perforation plates or pit membranes in a way that aids expansin function for

366 loosening of cellulose microfibrils, or vice versa. 
The distinct phylogenies of the Et-exlx and Et-gh5 ORFs, and their genomic architecture

371 located directly adjacent to each other in the same operon. Only in E. tracheiphila, P. stewartii, and $D$. dadantii is the exlx homolog directly adjacent - but not fused to - the gh5 homolog. This suggests that during a horizontal gene transfer event between an Enterobacteriaceae donor and recipient, an expansin integrated by random chance adjacent to a GH5, and the two ORFs in this operon are now being horizontally transferred together. The assembled protein complex through xylem, promoting the fitness of the host bacteria and providing opportunities for further in temperate Eastern North America - one of the world's most intensively cultivated regions - 

and are among the only herbivores that can detoxify 'cucurbitacins' (oxygenated tetracyclic

411 triterpene), which are a class of secondary metabolites produced by many Cucurbitaceae $(35,84$,

non-canonical virulence mechanisms. The recent realization that microbial expansin genes are present in phylogenetically diverse xylem-colonizing bacterial and fungal species - including almost all of the most economically damaging bacterial and fungal wilt pathogens - and the function of expansins to increase E. tracheiphila virulence suggest these genes may be an underappreciated virulence factor $(7,8,80,81)$. The emergence of virulent plant pathogens that systemically colonize xylem is especially alarming because plants do not have inherent genetic resistance against xylem-dwelling vascular pathogens (82). That expansin genes can confer an increase in pathogen virulence, are present in many damaging wilt-inducing agricultural plant pathogens, and are amenable to horizontal gene transfer should raise concerns about whether this gene is a more important virulence factor of agricultural plant pathogens than currently recognized.

\section{Methods}

\section{Study System}

E. tracheiphila is one of the few plant pathogenic bacterial species that moves systemically through xylem and causes host death, compared to most species that cause localized foliar lesions (83). E. tracheiphila is obligately vector-transmitted by two species of highly specialized leaf beetles, the striped cucumber beetle Acalymma vittatum and the spotted cucumber beetle Diabrotica undecimpunctata howardii (Coleoptera: Chrysomelidae: Luperini: Diabroticina). These herbivores have co-evolved with wild Cucurbita spp. in the New World, 85). The striped cucumber beetle (Acalymma vittatum), which is obligately dependent on 
413 Cucurbita in all life stages, is the predominant vector species driving E. tracheiphila epidemics

$414(40,67,86)$. Striped cucumber beetles acquire E. tracheiphila by feeding on wilting, infective

415 foliage, which is physically easier for them to consume than non-wilting foliage $(36,45) . E$.

416 tracheiphila colonizes the beetle hindgut (40,87-89), and beetles can transmit E. tracheiphila

417 when frass (poop) from infective beetles is deposited near recent feeding wounds on foliage, or

418 on floral nectaries $(36,40,43,86)$. The only known overwinter reservoir for E. tracheiphila is

419 infective cucumber beetles, which diapause as adults and infect new seedlings in early spring

420 when they emerge $(39,40,45,86,89,90)$.

Erwinia tracheiphila is an example of a plant pathogen that has recently emerged into a

422 new ecological niche created by construction of homogeneous agro-ecosystems $(34,35,37)$.

423 Analysis of the E. tracheiphila genome shows this species has undergone among the most

424 dramatic structural genomic changes of any bacterial pathogen, of any host species. These

425 changes include genome decay through pseudogenization, invasion and proliferation of mobile

426 genetic elements, and horizontal gene acquisitions. Together, these are the canonical genomic

427 signatures of a recent specialization on a new host species or population $(34,37,38)$. Erwinia

428 tracheiphila only infects few species in two genera of the cosmopolitan plant family

429 Cucurbitaceae. One of the genera that suffers economic losses, Cucurbita spp. (squash, pumpkin,

430 zucchini and some gourds), are native to the New World tropics and subtropics (91, 92). Two

431 Cucumis spp. (cucumber Cucumis sativus; and muskmelon Cucumis melo) native to the Old

432 World tropics and subtropics are the most susceptible hosts to E. tracheiphila infection, and the

433 introduction of highly susceptible Cucumis crop plants into temperate Eastern North America

434 likely drove the recent emergence of this pathogen (93-95). While these susceptible cucurbit 
cultivars are among the highest acreage crop plants globally (http://www.fao.org/faostat/), E.

tracheiphila only occurs in temperate Eastern North America $(34,96)$.

\section{Bacterial strains, culture media and plant cultivation}

439 All bacterial strains used in this study are listed in Supplemental Table 1. Throughout this work,

440 we used a rifampicin resistant variant of Erwinia tracheiphila BHKYR (Wt) (34). Escherichia

441 coli TOP10 and PIR1 strains for used for routine cloning, and the $E$. coli strain S17-1 $\lambda$ was used

442 as the donor for conjugation. E. tracheiphila was grown in KB liquid media or agar at room

443 temperature (RT), and E. coli strains in LB media or agar at $37^{\circ} \mathrm{C}$, unless otherwise specified.

444 Antibiotics were added to liquid or agar media at the following concentrations: rifampicin, 50

$445 \mu \mathrm{g} / \mathrm{ml}$; ampicillin or carbenicillin, $100 \mu \mathrm{g} / \mathrm{ml}$; chloramphenicol $5 \mu \mathrm{g} / \mathrm{ml}$; kanamycin $50 \mu \mathrm{g} / \mathrm{ml}$.

446 All in planta experiments were conducted with organic 'Dixie' variety crookneck squash bought

447 from Johnny's Seeds (https://www.johnnyseeds.com/). Plants were grown in potting mix in

448 standard six cell seedling trays in a greenhouse environment set to $25^{\circ} \mathrm{C}, 70 \%$ humidity, and a 12

449 hr day: $12 \mathrm{hr}$ night light cycle.

$451 \quad$ Visualization of fluorescent Erwinia tracheiphila in wilting squash seedlings

452 E. tracheiphila BuffGH was transformed with a plasmid carrying the mCherry gene for

453 visualization of fluorescent cells in symptomatic squash seedlings. Competent E. tracheiphila

454 were prepared as described previously $(34,97)$. Briefly, cells were prepared by growing $E$.

455 tracheiphila to an $\mathrm{OD}_{600}$ of 0.02 . Cells were then washed with decreasing volumes, once with 456 chilled sterile Milli-Q water and twice with 10\% glycerol, and resuspended in 1/100 volume of

457 chilled 10\% glycerol. Plasmid pMP7605 was used for electroporation in a 0.2 -cm cuvette, at 2.5 
$\mathrm{kV}$ for 5.2 to $5.8 \mathrm{~ms}$. Cells were incubated at room temperature without shaking for $1 \mathrm{~h}$ in $3 \mathrm{ml}$

KB liquid and then plated in KB agar with ampicillin. Colonies of fluorescent E. tracheiphila Et

460 (pMP605) were obtained after 5 days at room temperature. Ten $\mu 1$ of a $E t$ (pMP7605) stationary

461 culture were used for inoculating two week-old squash seedlings (at the two leaf stage), and

462 confocal microscopic observations were performed once symptoms appear using fresh

463 longitudinal cuts of the inoculated petiole.

464

Phylogenetic reconstruction of the expansin and endoglucanase genes and comparison of

domain architecture

467 The amino acid sequences of the expansin (WP_046372116.1) and gh5 (WP_016193008.1)

468 ORFs in the Erwinia tracheiphila reference strain (31) were used as queries to identify expansin 469 and gh5 homologs using the BLASTP web interface (98). A taxonomically representative sample 470 of the top BLASTP hits for each gene were aligned using MAFFT v. 7.305b and default 471 parameters (99). The expansin alignment was trimmed visually such that the two canonical 472 expansin domains were conserved in the alignment, and the gh5 alignment was trimmed with 473 trimAI using the -automated 1 option (100). For both alignments ProtTest v. 3.4 .2 was used to 474 identify the best-fitting substitution model by BIC score, which was WAG+G for the expansin 475 gene alignment and $\mathrm{LG}+\mathrm{I}+\mathrm{G}$ for the GH5 alignment (101). The GyrB species tree was 476 constructed by using the E. tracheiphila GyrB sequence (KKF36621.1) as a query on the

477 BLASTP web interface (98). The GyrB amino acid sequences from species known to have an 478 expansin gene or an expansin fusion to a domain from a carbohydrate active protein were

479 downloaded and added to a multi-fasta. The GyrB sequences were aligned with MAFFT v. $480 \quad 7.305 b$ and default parameters (99). 
Phylogenetic trees were reconstructed using maximum likelihood with RAxML (102) and

reconstructed with 1000 bootstrap pseudoreplicates, and the GH5 and GyrB trees were

reconstructed with 100 bootstrap pseudoreplicates. The bootstrapped pseudosamples were

summarized with SumTrees v. 4.4 .0 (104). The resulting phylogeny was visualized in the R

\section{Construction of deletion mutants}

493 Mutants with a deletion in the exlx-gh5 operon, exlx gene, gh5 gene, the Type IV pili operon and

494 the fliC gene were generated from an E. tracheiphila isolate BHKYR parental strain by double

495 homologous recombination, using the suicide plasmid pDS132 (108). This plasmid was

496 improved by inserting in the $X b a \mathrm{I}$ site, a constitutive $m$ Cherry gene amplified from plasmid

497 pMP7605 (109) using primers JR72 and JR73 (Supplemental Table 2). The resulting plasmid

498 (pJR74, Supplemental Table 1) allows rapid screening of conjugants colonies and colonies that

499 have lost the plasmid. For the target genomic region to create each mutant, regions upstream of

500 the target locus were amplified with primers pair F5 and R5, and downstream regions were

501 amplified with primer pair F3 and R3 (See Supplemental Table 2 for specific primer names and

502 sequences). An ampicillin resistance bla gene, coding for Beta-lactamase was amplified from

503 pDK46 (97) using primers LS23 and LS24. Constructions consisting on each upstream and 
504

505

506

507

508

509

510

511

512

513

514

515

516

517

518

downstream region flanking the bla gene were used for exlx-gh5, gh5, fliC and Type 4 Pili mutants, while a construction with no flanked antibiotic cassette was prepared for the exlx deletion. All constructions were assembled using the Gibson Assembly Master Mix (New England Biolabs, Ipswich, MA), and then each was reamplified with nested primers containing SacI restriction site (primers SacI-F and SacI-R, Supplemental Table 2). Constructions for exlxgh5, exlx, gh5, fliC and Type 4 Pili deletion were inserted into the SacI site of plasmid pJR74, obtaining plasmids pJR150, pJR323, pJR324, pJR74a and pJR149, respectively (Supplemental Table 1). These plasmids were transformed into $E c$-PIR1 for preservation, and then into $E c$-S17 for conjugation using E. tracheiphila as recipient. MCherry fluorescent E. tracheiphila conjugants were obtained in $\mathrm{KB}$ agar with rifampicin and chloramphenicol, then a few colonies were picked and grown in $3 \mathrm{ml}$ liquid $\mathrm{KB}$ with chloramphenicol to stationary phase, and $100 \mu \mathrm{l}$ were spread in $\mathrm{KB}$ agar with 5\% sucrose and carbenicillin (or no antibiotic in the case of exlx deletion). Non-fluorescent, chloramphenicol-sensitive colonies were picked, PCR checked for the correct deletion and cryogenically stored in $15 \%$ glycerol at $-80 \mathrm{C}$.

\section{Genetic complementation}

A new integration plasmid, specific for a neutral region in the chromosome of EtBHKYR, was constructed from plasmid pJR74. To create this plasmid, two $\approx 0.8 \mathrm{~Kb}$ adjacent DNA fragments were PCR amplified form Et-BHKYR genomic DNA using primer pairs JR143JR144, and JR145-JR146 (Supplemental Table 2). These fragments were ligated using the Gibson Assembly Master Mix (New England Biolabs, Ipswich MA), and reamplified using primers JR143 and JR146. The $\approx 1.6 \mathrm{~Kb}$ product was inserted in the SacI site of pJR74, generating plasmid pJR315 (Supplemental Table 1). Single cutting XhoI and BglII sites were 
engineered in the middle of the amplified neutral regions, which can be used for the insertion of

gene, the genomic region together with its natural promoter were amplified from E. tracheiphila genomic DNA using primers JR152 and JR154, or JR152 and JR153 (Supplemental Table 2)

531 respectively, and DNA products were inserted into the XhoI site of pJR315. Each resulting

532 plasmid was transformed into $E c-\mathrm{S} 17-1 \lambda$ cells, which were then used as donors for conjugation

533 with mutant strains $\Delta e x l x-g h 5, \Delta e x l x$ or $\Delta g h 5$ as recipients. Conjugant colonies were used for

534 negative selection with sucrose, as described above, and colonies carrying the exlx-gh5 operon or

535 the exlx gene integrated in the expected site were confirmed by PCR.

\section{In planta inoculation experiments}

538 In planta virulence assays were performed by inoculating squash seedlings with E. tracheiphila

539 Wt and derived strains, and monitoring wilt symptom development for approximately three

540 weeks (between 21-25 days per experiment). To create inoculum, one bacterial colony of each

541 strain was picked and added to $3 \mathrm{ml}$ of liquid $\mathrm{KB}$ media with the appropriate antibiotic, and

542 grown with shaking for $24 \mathrm{~h}$. Then, 2-3 week-old squash seedlings (2-3 true leaves) were

543 inoculated by manually inducing a wound where xylem was exposed in the petiole at the base of

544 the first true leaf and adding $10 \mu \mathrm{l}$ of culture containing $\approx 1 \times 10^{7}$ bacterial cells directly into the

545 wound. Plants were kept at $25^{\circ} \mathrm{C}, 70 \%$ humidity, and a $12 \mathrm{hr}$ day: $12 \mathrm{hr}$ night light cycle $25 \mathrm{C}$, and

546 monitored daily for appearance of first symptoms in the inoculated leaf, appearance of wilt

547 symptoms in a second non-inoculated leaf, and plant death. 
Bacterial colony forming units (CFU) counts were determined from plants inoculated with Et-

BHKY and derived strains. Bacterial cells can be obtained directly from petioles of infected

plants (Figure 4D). Two cm samples of the petiole from the inoculated leaf, or from a second

non-inoculated leaf were cut from the plants and washed briefly with $70 \%$ ethanol $(\mathrm{EtOH})$.

554 Excess EtOH was removed with a paper towel and petioles were surface-sterilized over a gas

555 flame for 1 second and placed in a sterile plastic petri dish. From each petiole sample, 10-15

556 disks small disks $(<1 \mathrm{~mm})$ were manually cut with a sterile blade and collected in a $2 \mathrm{ml}$

557 microtube. The weight of each $2 \mathrm{ml}$ tube with all leaf disks was recorded to be used for

558 normalizing CFU per gram of plant tissue in each sample, and $500 \mu$ of chilled PBS was added

559 to each tube. After an incubation of $40 \mathrm{~min}$ on ice (vortexing every $10 \mathrm{~min}$ ) $200 \mu \mathrm{l}$ of PBS from

560 each tube was pipetted into a new microtube and used for serial dilutions and plating onto KB

561 agar with rifampicin. Bacterial CFU per gram of fresh tissue was calculated.

562 For obtaining CFUs of individual strains in plants co-inoculated with E. tracheiphila Wt

563 and $\Delta e x l x$-gh5 mutant, serial dilutions were plated in both $\mathrm{KB}$ with rifampicin and $\mathrm{KB}$ with

564 rifampicin and carbenicillin agar plates. CFU of carbenicillin resistant colonies represent the

$565 \Delta$ sexlx-gh5 strain. CFUs of Wt was determined as the count of total CFUs - carbenicillin resistant

566 CFUs.

Statistics

569 Statistical analyses were performed using Prism version 7.0 (GraphPad Software, La Jolla

570 California USA, www.graphpad.com). Curves following initial symptoms in first leaf, systemic

571 wilt in second leaf, and plant death from each experiment were compared using the built-in Log-

572 rank (Mantel-Cox) test for survival analysis. In the cases where significant differences were 
573 found $(p<0.05)$, pairwise comparisons were tested using the same analysis $(110)$. For

574 comparisons of bacterial CFU in planta, CFU data and its $\log _{10}$-transformed values were checked

575 for Gaussian distribution using the Shapiro-Wilk normality test. Since neither CFU data

576 distribution nor the transformed $\log _{10}$ values distribution passed the normality test, the Kruskal-

577 Wallis non-parametric was used test to analyze if the medians vary significantly among

578 experimental groups $(p<0.05)$. In the cases where differences were found, Dunn's multiple

579 comparisons test was used to test for pairwise differences between groups.

$581 \quad$ Testing for cellulase and xylanase activity

582 Cellulase activity from cell-free supernatants of Wt and $\Delta e x l x$-gh5 cultures were tested for

583 extracellular enzymatic activity against cellulose. The Wt and $\Delta e x l x$-gh 5 strains were grown in

$58410 \mathrm{ml}$ of liquid $\mathrm{KB}$ media for $48 \mathrm{H}$. Cultures were centrifuged at 7,000 rpm for $10 \mathrm{~min}$, and each

585 supernatant was filter-sterilized. Supernatants and $1 \mathrm{mg} / \mathrm{ml}$ cellulase (Sigma), were spotted in $1 \%$

586 agar, $1 \%$ Carboxy Methil Cellulose (CMC) plates. Plates were then incubated at $30^{\circ} \mathrm{C}$ for $48 \mathrm{~h}$,

587 and flooded with Gram's Iodine. Halos were imaged after $24 \mathrm{~h}$ at RT.

A colony of E. tracheiphila grown on $\mathrm{KB}$ agar plates was used to test for extracellular

589 xylanase activity. A xylanase producing strain of Streptomyces lividens was used as a positive

590 control. Bacterial culture from each species was spotted on the surface of a KB agar plate, and

591 grown at RT for 4 days. An overlay of 1\% agar and 1\% xylan was spread on top of the grown

592 colonies, and plates were incubated at $30^{\circ} \mathrm{C}$ for $48 \mathrm{~h}$. Plates were flooded with $1 \%$ congo red and

593 incubated for 10 min before discarding the congo red solution. Plates were then flooded with 1N

$594 \mathrm{NaOH}$, and incubated for $10 \mathrm{~min}$. $\mathrm{NaOH}$ was discarded and plates were imaged after $24 \mathrm{~h}$ at

595 room temperature. 


\section{Acknowledgements}

598 This work was supported by Fundación Mexico en Harvard, and Conacyt grant 237414 to JR,

599 NSF postdoctoral fellowship DBI-1202736 to LRS and NIH Grant GM58213 to RK.

600 We thank all members of the Kolter lab, and Einat Segev, William R. Chase and Olga

601 Zhaxybayeva for valuable feedback and discussion. We thank the staff at the Harvard Arnold

602 Arboretum for assistance in plant cultivation, use of growth facilities and use of the confocal

603 microscope. Dominique Schneider kindly donated the plasmid pDS132.

604

605

606

607

608

609

610

\section{Tables}

Table 1. Summary of in planta inoculation experiment comparing virulence traits between strains Wt, $\Delta$ exlx-gh5 mutant, $\Delta$ exlx-gh5 (cEXLX-GH5) complemented mutant, $\Delta$ exlx mutant and $\Delta \operatorname{exl} x$ (cEXLX) complemented mutant (corresponding to Figure 3A).

\begin{tabular}{|c|c|c|c|c|c|c|c|}
\hline \multirow[b]{2}{*}{$\begin{array}{l}\text { Inoculated } \\
\text { strain }\end{array}$} & \multicolumn{4}{|c|}{$\begin{array}{l}\text { No. of plants } \\
\text { (\% of total) }\end{array}$} & \multicolumn{3}{|c|}{ Average no. of days until: } \\
\hline & $\begin{array}{c}\text { Total } \\
\text { inoculated }\end{array}$ & $\begin{array}{l}\text { Showing } \\
\text { local } \\
\text { symptoms }\end{array}$ & $\begin{array}{l}\text { Showing } \\
\text { systemic } \\
\text { symptoms }\end{array}$ & Died & $\begin{array}{c}\text { Local } \\
\text { symptoms } \\
\text { in first } \\
\text { leaf }\end{array}$ & $\begin{array}{c}\text { Systemic } \\
\text { symptoms } \\
\text { in second } \\
\text { leaf }\end{array}$ & Death \\
\hline $\mathrm{Wt}$ & 20 & $\begin{array}{c}22 \\
(100 \%)\end{array}$ & $\begin{array}{c}20 \\
(100 \%)\end{array}$ & $\begin{array}{c}17 \\
(85 \%)\end{array}$ & 7.40 & 13.70 & 15.29 \\
\hline$\Delta e x l x-g h 5$ & 22 & $\begin{array}{c}22 \\
(100 \%)\end{array}$ & $\begin{array}{c}20 \\
(91 \%)\end{array}$ & $\begin{array}{c}5 \\
(22 \%)\end{array}$ & 10.45 & 17.65 & 19.40 \\
\hline $\begin{array}{c}\Delta e x l x-g h 5 \\
\text { (cEXLX-GH5) }\end{array}$ & 22 & $\begin{array}{c}22 \\
(100 \%)\end{array}$ & $\begin{array}{c}22 \\
(100 \%)\end{array}$ & $\begin{array}{c}13 \\
(59 \%)\end{array}$ & 10.14 & 14.77 & 16.31 \\
\hline$\Delta e x l x$ & 24 & $\begin{array}{c}24 \\
(100 \%)\end{array}$ & $\begin{array}{c}23 \\
(95 \%)\end{array}$ & $\begin{array}{c}12 \\
(50 \%)\end{array}$ & 10.29 & 17.43 & 20.33 \\
\hline $\begin{array}{c}\Delta e x l x \\
(\mathrm{cEXLX})\end{array}$ & 24 & $\begin{array}{c}24 \\
(100 \%)\end{array}$ & $\begin{array}{c}24 \\
(100 \%)\end{array}$ & $\begin{array}{c}15 \\
(62 \%)\end{array}$ & 8.83 & 14.46 & 15.53 \\
\hline
\end{tabular}

611

612

613

614 Table 2. Log-rank (Mantel-Cox) tests for assessing statistical differences in virulence between

615 Wt, $\Delta e x l x$-gh5 mutant, $\Delta e x l x$-gh5 (cEXLX-GH5) complemented mutant, $\Delta e x l x$ mutant and $\Delta e x l x$ 
616 (cEXLX) complemented mutant via in planta inoculation experiments (corresponding to Figure

$617 \quad 3 \mathrm{~A})$.

618

\begin{tabular}{lcc|cc|cc} 
& \multicolumn{2}{c|}{$\begin{array}{c}\text { First leaf } \\
\text { symptoms }\end{array}$} & \multicolumn{2}{c|}{$\begin{array}{c}\text { Second systemic } \\
\text { leaf symptoms }\end{array}$} & \multicolumn{2}{c}{ Death of plants } \\
\cline { 2 - 8 } & $\begin{array}{c}\text { Chi } \\
\text { square }\end{array}$ & $p$ value & $\begin{array}{c}\text { Chi } \\
\text { square }\end{array}$ & $p$ value & $\begin{array}{c}\text { Chi } \\
\text { square }\end{array}$ & $p$ value \\
\hline All groups & 17.45 & 0.0016 & 28.51 & $<0.0001$ & 22.02 & 0.0002 \\
Wt vs $\Delta$ exlx-gh5 & 9.787 & 0.0018 & 16.4 & $<0.0001$ & 20.87 & $<0.0001$ \\
Wt vs $\Delta$ exlx-gh5 (cEXLX-GH5) & 11.04 & 0.0009 & 1.5 & 0.2206 & 3.939 & 0.0472 \\
Wt vs $\Delta$ exlx & 12.09 & 0.0005 & 16.44 & $<0.0001$ & 9.348 & 0.0022 \\
Wt vs $\Delta$ exlx (cEXLX) & 4.321 & 0.0376 & 0.9923 & 0.3192 & 2.497 & 0.1141 \\
\hline
\end{tabular}

622 Table 3. Summary of in planta inoculation experiment comparing virulence traits of Wt, $\Delta g h 5$

623 mutant and $\Delta g h 5$ (cEXLX-GH5) complemented mutant (corresponding to Figure 3B).

624

625

626

627

628

629

630

\begin{tabular}{|c|c|c|c|c|c|c|c|}
\hline \multirow[b]{2}{*}{$\begin{array}{l}\text { Inoculated } \\
\text { strain }\end{array}$} & \multicolumn{4}{|c|}{$\begin{array}{l}\text { No. of plants } \\
\text { (\% of total) }\end{array}$} & \multicolumn{3}{|c|}{ Average no. of days until: } \\
\hline & $\begin{array}{c}\text { Total } \\
\text { inoculated }\end{array}$ & $\begin{array}{l}\text { Showing } \\
\text { local } \\
\text { symptoms }\end{array}$ & $\begin{array}{l}\text { Showing } \\
\text { systemic } \\
\text { symptoms }\end{array}$ & Died & $\begin{array}{c}\text { Local } \\
\text { symptoms } \\
\text { in first } \\
\text { leaf }\end{array}$ & $\begin{array}{c}\text { Systemic } \\
\text { symptoms } \\
\text { in second } \\
\text { leaf }\end{array}$ & Death \\
\hline $\mathrm{Wt}$ & 22 & $\begin{array}{c}22 \\
(100 \%) \\
12\end{array}$ & $\begin{array}{c}18 \\
(81 \%) \\
8\end{array}$ & $\begin{array}{c}17 \\
(77 \%) \\
6\end{array}$ & 11.82 & 13.61 & 18.82 \\
\hline$\Delta g h 5$ & 21 & $(57 \%)$ & $(38 \%)$ & $(28 \%)$ & 13.25 & 15.38 & 19.33 \\
\hline$\frac{\Delta g h 5}{\left(\mathrm{CXI} \mathrm{X}_{-} \mathrm{GH}\right)}$ & 22 & $\begin{array}{c}21 \\
(95 \%)\end{array}$ & $\begin{array}{c}14 \\
(66 \%)\end{array}$ & $\begin{array}{c}13 \\
(59 \%)\end{array}$ & 1267 & 1300 & 1854 \\
\hline
\end{tabular}

Table 4. Log-rank (Mantel-Cox) tests for assessing statistical differences in virulence between strains Wt, $\Delta g h 5$ mutant and $\Delta g h 5$ (cEXLX-GH5) complemented mutant (corresponding to Figure 3B).

Compared treatment groups

\begin{tabular}{|c|c|c|c|c|c|}
\hline \multicolumn{2}{|c|}{$\begin{array}{c}\text { First leaf } \\
\text { symptoms }\end{array}$} & \multicolumn{2}{|c|}{$\begin{array}{l}\text { Second systemic } \\
\text { leaf symptoms }\end{array}$} & \multicolumn{2}{|c|}{ Death of plants } \\
\hline Chi & $p$ value & Chi & $p$ value & & $p$ value \\
\hline
\end{tabular}


631

632

633

634

635

636

637

638

639

640

641

642

643 644 Figure 9).

645

Table 5. Summary of in planta inoculation experiment comparing virulence traits between

strains $\mathrm{Wt}, \Delta f l i C$ mutant and $\triangle T 4 P$ mutant (corresponding to Figure 7).

\begin{tabular}{ccccc|ccc} 
& \multicolumn{3}{c|}{ No. of plants (\% of total) } & \multicolumn{3}{c}{ Average no. of days until: } \\
\cline { 2 - 8 } $\begin{array}{c}\text { Inoculated } \\
\text { strain }\end{array}$ & $\begin{array}{c}\text { Total } \\
\text { inoculated }\end{array}$ & $\begin{array}{c}\text { Showing } \\
\text { local } \\
\text { symptoms }\end{array}$ & $\begin{array}{c}\text { Showing } \\
\text { systemic } \\
\text { symptoms }\end{array}$ & Died & $\begin{array}{c}\text { Local } \\
\text { symptoms } \\
\text { in first } \\
\text { leaf }\end{array}$ & $\begin{array}{c}\text { Systemic } \\
\text { symptoms } \\
\text { in second } \\
\text { leaf }\end{array}$ & Death \\
\hline Wt & 21 & $\begin{array}{c}21 \\
(100 \%)\end{array}$ & $\begin{array}{c}21 \\
(100 \%) \\
22\end{array}$ & $\begin{array}{c}14 \\
(66 \%)\end{array}$ & 9.43 & 13.62 & 18.86 \\
$\Delta f l i C$ & 22 & $\begin{array}{c}22 \\
(100 \%) \\
(100 \%)\end{array}$ & $\begin{array}{c}13 \%) \\
(59 \%)\end{array}$ & 10.23 & 13.45 & 17.54 \\
$\Delta T 4 P$ & 17 & $(100 \%)$ & $(100 \%)$ & $(52 \%)$ & 9.18 & 14.53 & 19.67 \\
\hline
\end{tabular}

Table 6. Log-rank (Mantel-Cox) tests for assessing statistical differences in virulence between strains $\mathrm{Wt}, \triangle f l i C$ mutant and $\triangle T 4 P$ mutant (corresponding to Figure 7).

\begin{tabular}{|c|c|c|c|c|c|c|}
\hline \multirow{2}{*}{$\begin{array}{l}\text { Compared } \\
\text { treatment groups }\end{array}$} & \multicolumn{2}{|c|}{$\begin{array}{c}\text { First leaf } \\
\text { symptoms }\end{array}$} & \multicolumn{2}{|c|}{$\begin{array}{c}\text { Second systemic leaf } \\
\text { symptoms }\end{array}$} & \multicolumn{2}{|c|}{ Death of plants } \\
\hline & $\begin{array}{c}\text { Chi } \\
\text { square }\end{array}$ & $p$ value & $\begin{array}{c}\text { Chi } \\
\text { square }\end{array}$ & $p$ value & $\begin{array}{c}\text { Chi } \\
\text { square }\end{array}$ & $p$ value \\
\hline All groups & 1.623 & 0.6543 & 1.324 & 0.7235 & 2.156 & 0.5406 \\
\hline
\end{tabular}

Table 7. Summary of in planta inoculation experiment comparing virulence traits between mutant strains $\Delta e x l x, \Delta g h 5$ and a $1: 1$ mix of both $\Delta e x l x$ and $\Delta g h 5$ mutants (corresponding to

\begin{tabular}{|c|c|c|c|c|c|c|c|}
\hline \multirow[b]{2}{*}{$\begin{array}{l}\text { Inoculated } \\
\text { strain }\end{array}$} & \multicolumn{4}{|c|}{ No. of plants (\% of total) } & \multicolumn{3}{|c|}{ Average no. of days until: } \\
\hline & $\begin{array}{c}\text { Total } \\
\text { inoculated }\end{array}$ & $\begin{array}{l}\text { Showing } \\
\text { local } \\
\text { symptoms }\end{array}$ & $\begin{array}{l}\text { Showing } \\
\text { systemic } \\
\text { symptoms }\end{array}$ & Died & $\begin{array}{c}\text { Local } \\
\text { symptoms } \\
\text { in first } \\
\text { leaf }\end{array}$ & $\begin{array}{c}\text { Systemic } \\
\text { symptoms } \\
\text { in second } \\
\text { leaf }\end{array}$ & Death \\
\hline$\Delta e x l x$ & 18 & $\begin{array}{c}15 \\
(83 \%)\end{array}$ & $\begin{array}{c}8 \\
(44 \%)\end{array}$ & $\begin{array}{c}3 \\
(16 \%)\end{array}$ & 9.33 & 16.25 & 17.33 \\
\hline
\end{tabular}


646

647

648

649

650

651

652

653

654

655

656

657

658

659

660

661

662

663

664

665

666

\begin{tabular}{|c|c|c|c|c|c|c|}
\hline \multirow{2}{*}{$\begin{array}{l}\text { Compared treatment } \\
\text { groups }\end{array}$} & \multicolumn{2}{|c|}{$\begin{array}{c}\text { First leaf } \\
\text { symptoms }\end{array}$} & \multicolumn{2}{|c|}{$\begin{array}{c}\text { Second systemic leaf } \\
\text { symptoms }\end{array}$} & \multicolumn{2}{|c|}{ Death of plants } \\
\hline & $\begin{array}{c}\text { Chi } \\
\text { square }\end{array}$ & $p$ value & $\begin{array}{c}\text { Chi } \\
\text { square }\end{array}$ & $p$ value & $\begin{array}{c}\text { Chi } \\
\text { square }\end{array}$ & $p$ value \\
\hline All groups & 0.5335 & 0.7659 & 0.05808 & 0.9714 & 0.2023 & 0.9038 \\
\hline
\end{tabular}

Table 8. Log-rank (Mantel-Cox) statistical test results for experiment comparing virulence of mutant strains $\Delta e x l x, \Delta g h 5$ and a 1:1 mix of both $\Delta e x l x$ and $\Delta g h 5$ mutants (corresponding to Figure 9).

\section{Figure captions}

Figure 1. Genomic context and phylogenies of the expansin and glycoside hydrolase 5 genes

\section{in Erwinia tracheiphila}

A) Genomic context of the expansin $(e x l x)$ and glycoside hydrolase 5 (gh5) open reading frames (ORFs) in Erwinia tracheiphila. The ORFs and intergenic spaces are drawn to scale, with the black line representing position on the chromosome, and each ORF as an arrow color-coded according to ab initio annotated function. The scale bar is the length in nucleotides of the ORFs and intergenic spaces.

B) Distribution of expansin (exlx) homologs in a taxonomically representative set of bacterial species. Branches are colored according to taxonomic assignments. The tree was reconstructed using maximum likelihood and should be considered unrooted. Numbers at nodes are bootstrap pseudoreplicate supports, and the scale bar is the number of amino acid substitutions per site. 
C) Distribution of glycoside hydrolase $5(\mathrm{gh} 5)$ homologs in a taxonomically representative set of species. Branches are colored according to taxonomic assignments, using the same color assignments as Figure 1B. The tree was reconstructed using maximum likelihood and should be considered unrooted. Numbers at nodes are bootstrap pseudoreplicate supports, and the scale bar

671 is the number of amino acid substitutions per site.

Figure 2. Co-occurrence of expansin genes with carbohydrate active domains. The GyrB

species tree of selected bacteria with an expansin gene, and several species without expansins. expansin gene, and the rectangles within the arrows indicate whether that ORF has an expansin domain, a carbohydrate active domain, or both. Homologous carbohydrate active domains are color-coded. Both expansin genes are shown for Streptomyces scabiei, the only microbial species to harbor two expansin homologs with signal peptides for secretion. Accession numbers of the depicted protein sequences, and accession numbers of several expansin homologs that do not

681 have predicted signal peptides for secretion and are not depicted in the figure, can be found in 682 Supplemental Table 3. The domains are drawn to scale. The tree was reconstructed using maximum likelihood with 100 bootstrap pseudoreplicates and should be considered unrooted.

686 development and plant death A) In planta inoculation experiment comparing virulence of $\mathrm{Wt}$, 
690

691

692

693

694

695

696

697

698

699

700

701

702

703

704

705

706

707

708

709

710

711

712

leaf, first appearance of systemic wilt symptoms in a second non-inoculated leaf and plant death for 23 days post inoculation (DPI). Summary and statistical analyses are in Tables 1-4. All samples sizes were between 18-22 individual plants per treatment.

\section{Figure 4. Visual comparison of wilt symptoms in squash seedlings after inoculation with} either the $\Delta e x l x-g h 5$ mutant or wild type Erwinia tracheiphila.
A) Non-inoculated squash seedling with no wilt symptoms
B) Squash seedling inoculated with

wild type E. tracheiphila that has developed systemic wilt symptoms C) Representative symptoms caused by inoculation with the $\Delta e x l x-g h 5$ mutant strain, where wilt often remains localized to the inoculated leaf without causing systemic wilt symptoms. D) Visible $E$. tracheiphila oozing from xylem in all vascular bundles of a symptomatic plant after a horizontal stem cross section cut. E) 20X confocal miscroscopy image of a longitudinal section of a symptomatic, E. tracheiphila infected Cucurbita pepo stem. Image is falsely colored so that plant structures are shown in blue and live E. tracheiphila bacterial cells are red.

\section{Figure 5. Systemic colonization capability of Wt and $\Delta e x l x-g h 5$ strains.}

Squash seedlings were inoculated with either Wt or $\Delta$ exlx-gh5. At 12 days post inoculation (DPI), bacterial concentration was determined in the inoculation site and in a petiole of a second, non-inoculated leaf. Mean $\pm \mathrm{SE}$ are plotted, and grey circles are individual biological replicates (Sample sizes, $n=9$ per treatment). Y-axis is the $\log _{10} \mathrm{CFU} / \mathrm{gram}$ fresh weight and is scaled to the lower limit of detection for the assay $\left(\log _{10} \mathrm{CFU} /\right.$ gram fresh weight $\left.=3\right)$. Brackets indicate pairwise statistical comparisons (Dunn's test) between two groups: ${ }^{*} P<0.005$; ns, non significant. 
714 Figure 6. Correlation of $\Delta e x l x$-gh5 concentration with symptom severity. Thirty squash

715 seedlings were inoculated with $\Delta$ exlx-gh5, and at 21 days post inoculation (DPI) all plants were

716 scored according to whether they remained healthy $(n=8)$, had developed wilt symptoms only in

717 the inoculated leaf $(n=12)$, or had developed systemic wilt symptoms $(n=10)$. CFU were then

718 counted at the inoculation site and at a second non-inoculated leaf requiring systemic movement.

719 Bars show mean \pm SE, and grey circles are individual biological replicates. $\mathrm{Y}$-axis is scaled to 720 the lower limit of detection for the assay $\left(\log _{10} \mathrm{CFU} /\right.$ gram fresh weight $\left.=3\right)$. Brackets indicate

721 pairwise statistical comparisons (Dunn's test) between two groups: * $P<0.05 ; * * P<0.005$; ns,

722 non significant.

723

Figure 7. Comparison of virulence between wild type, flagellar deletion mutant and Type

725 IV Pili deletion mutant. Squash seedlings were inoculated with either Wt, a flagellar deletion

726 mutant $(\Delta f l i C)$ or a Type IV Pili deletion mutant $(\Delta T 4 P)$. Inoculated plants were monitored for

727 first appearance of wilt symptoms in the inoculated leaf, first appearance of systemic wilt

728 symptoms in a second non-inoculated leaf and plant death for 25 days post inoculation (DPI). All

729 samples sizes were between 17-22 individual plants per treatment. Summary and statistical

$730 \quad$ analyses are in Tables 5 and 6.

731

732 Figure 8. In trans complementation of $\Delta$ exlx-gh5 and Wt. (A) Plants were singly inoculated

733 with either Wt or $\Delta e x l x$-gh5, and (B) Plants were co-inoculated with a 1:1 mix of Wt \& $\Delta e x l x$ -

734 gh5. In both single and co-inoculation experiments, CFU were counted at 1 day post inoculation

735 (DPI) from the local inoculation site and at 12 DPI from the petiole of a second non-inoculated 
leaf. Y-axis is scaled to the lower limit of detection for the assay $\left(\log _{10} \mathrm{CFU} / \mathrm{gram}\right.$ fresh weight $=$

3). Bars show mean $\pm \mathrm{SE}$, and grey circles are individual biological replicates. Sample size, $\mathrm{n}=4$

per treatment.

Figure 9. In trans complementation of $\Delta e x l x$ and $\Delta g h 5$. Plants were co-inoculated with both

741 wilt symptoms in the inoculated leaf, first appearance of systemic wilt symptoms in a second leaf

742 and plant death for 21 days post inoculation (DPI). Sample sizes are $n=18$ per treatments.

743 Summary and statistical analyses are in Tables 7 and 8.

\section{References}

1. Haichar FEZ, Marol C, Berge O, Rangel-castro J, Prosser JI, Balesdent J, Heulin T, Achouak W. 2008. Plant host habitat and root exudates shape soil bacterial community structure. The ISME Journal 2:1221-30.

2. Shi S, Richan Condron LM. 2011. Effects of selected root exudate components on soil bacterial communities. FEMS Microbiology Ecology 77:600-610.

3. Lindow SE, Brandl MT. 2003. Microbiology of the Phyllosphere. Applied and

4. Huang X, Chaparro JM, Reardon KF, Zhang R. 2014. Rhizosphere interactions: root exudates, microbes and microbial communities. Botany.

5. Miwa H, Okazaki S. 2017. How effectors promote beneficial interactions. Current Opinion in Plant Biology 38:148-154.

6. Wees SCV, Ent SVd, Pieterse CM. 2008. Plant immune responses triggered by beneficial microbes. Current Opinion in Plant Biology 11:443-448.

7. Cosgrove DJ. 2017. Microbial Expansins. Annual Review of Microbiology 71:479-497.

8. Chase WR, Zhaxybayeva O, Rocha J, Cosgrove DJ, Shapiro LR. 2019. From morphogenesis to pathogenesis: A cellulose loosening protein is one of the most widely shared tools in nature. bioRxiv.

9. Georgelis N, Nikolaidis N, Cosgrove DJ. 2014. Biochemical analysis of expansin-like proteins from microbes. Carbohydrate Polymers 100:17-23.

10. Nikolaidis N, Doran N, Cosgrove DJ. 2013. Plant expansins in bacteria and fungi: evolution by horizontal gene transfer and independent domain fusion. Molecular Biology and Evolution 31:376-386. 
770 11. Cosgrove DJ. 2000. Loosening of plant cell walls by expansins. Nature 407:321-326.

771 12. Sampedro J, Cosgrove DJ. 2005. The expansin superfamily. Genome biology 6:242.

772 13. Cosgrove DJ. 2015. Plant expansins: diversity and interactions with plant cell walls.

773

774 Current Opinion in Plant Biology 25:162-172.

775

776

14. Chen F, Bradford KJ. 2000. Expression of an expansin is associated with endosperm weakening during tomato seed germination. Plant Physiology 124:1265-1274.

777

778

779

15. Brummell DA, Harpster MH, Civello PM, Palys JM, Bennett AB, Dunsmuir P. 1999.

780

781

782

783

784

785

Modification of expansin protein abundance in tomato fruit alters softening and cell wall polymer metabolism during ripening. The Plant Cell 11:2203-2216.

16. Cho H-T, Cosgrove DJ. 2000. Altered expression of expansin modulates leaf growth and pedicel abscission in Arabidopsis thaliana. Proceedings of the National Academy of Sciences 97:9783-9788.

17. Li Y, Darley CP, Ongaro V, Fleming A, Schipper O, Baldauf SL, McQueen-Mason SJ. 2002. Plant expansins are a complex multigene family with an ancient evolutionary origin. Plant Physiology 128:854-864.

786

18. Cosgrove DJ, Li LC, Cho H-T, Hoffmann-Benning S, Moore RC, Blecker D. 2002. The growing world of expansins. Plant and Cell Physiology 43:1436-1444.

19. Georgelis N, Nikolaidis N, Cosgrove DJ. 2015. Bacterial expansins and related proteins from the world of microbes. Applied Microbiology and Biotechnology 99:3807-3823.

20. Kerff F, Amoroso A, Herman R, Sauvage E, Petrella S, Filée P, Charlier P, Joris B, Tabuchi A, Nikolaidis N, Cosgrove DJ. 2008. Crystal structure and activity of Bacillus subtilis YoaJ (EXLX1), a bacterial expansin that promotes root colonization. Proceedings of the National Academy of Sciences 105:16876-16881.

21. Kende H, Bradford K, Brummell D, Cho H-T, Cosgrove D, Fleming A, Gehring C, Lee Y, McQueen-Mason S, Rose J. 2004. Nomenclature for members of the expansin superfamily of genes and proteins. Plant Molecular Biology 55:311-314.

22. Saloheimo M, Paloheimo M, Hakola S, Pere J, Swanson B, Nyyssönen E, Bhatia A, Ward M, Penttilä M. 2002. Swollenin, a Trichoderma reesei protein with sequence similarity to the plant expansins, exhibits disruption activity on cellulosic materials. European Journal of Biochemistry 269:4202-4211.

801

23. Brotman Y, Briff E, Viterbo A, Chet I. 2008. Role of swollenin, an expansin-like protein from Trichoderma, in plant root colonization. Plant Physiology 147:779-789.

803

804

805

24. Tancos MA, Lowe-Power TM, Peritore-Galve FC, Tran TM, Allen C, Smart CD. 2018.

26. Plant-like bacterial expansins play contrasting roles in two tomato vascular pathogens. Molecular Plant Pathology 19:1210-1221.

25. Chalupowicz L, Barash I, Reuven M, Dror O, Sharabani G, Gartemann KH, Eichenlaub R, Sessa G, Manulis-Sasson S. 2017. Differential contribution of Clavibacter michiganensis ssp. michiganensis virulence factors to systemic and local infection in tomato. Molecular Plant Pathology 18:336-346.

810

811

812 Laine MJ, Haapalainen M, Wahlroos T, Kankare K, Nissinen R, Kassuwi S, Metzler MC. 2000. The cellulase encoded by the native plasmid of Clavibacter michiganensis ssp. sepedonicus plays a role in virulence and contains an expansin-like domain. Physiological and Molecular Plant Pathology 57:221-233. 
813 27. Hwang IS, Oh E-J, Lee HB, Oh C-S. 2019. Functional characterization of two cellulase

814

815

816

817

818

819

820

821

822

823

824

825

826

827

828

829

830

831

832

833

834

835

836

837

838

839

840

841

842

843

844

845

846

847

848

849

850

851

852

853

854

genes in the Gram-positive pathogenic bacterium Clavibacter michiganensis for wilting in tomato. Molecular Plant-Microbe Interactions 32:491-501.

28. Hwang IS, Oh EJ, Kim D, Oh CS. 2018. Multiple plasmid-borne virulence genes of Clavibacter michiganensis ssp. capsici critical for disease development in pepper. New Phytologist 217:1177-1189.

29. Olarte-Lozano M, Mendoza-Nuñez MA, Pastor N, Segovia L, Folch-Mallol J, MartínezAnaya C. 2014. PcExl1 a novel acid expansin-like protein from the plant pathogen Pectobacterium carotovorum, binds cell walls differently to BsEXLX1. PLoS One 9:e95638.

30. Jahr H, Dreier J, Meletzus D, Bahro R, Eichenlaub R. 2000. The endo- $\beta-1,4$-glucanase CelA of Clavibacter michiganensis subsp. michiganensis is a pathogenicity determinant required for induction of bacterial wilt of tomato. Molecular Plant-Microbe Interactions 13:703-714.

31. Shapiro LR, Scully ED, Roberts D, Straub TJ, Geib SM, Park J, Stephenson AG, Rojas ES, Liu Q, Beattie G, Gleason M, Moraes CMD, Mescher MC, Fleischer SJ, Kolter R, Pierce N, Zhaxybayeva O. 2015. Draft genome sequence of Erwinia tracheiphila, an economically important bacterial pathogen of cucurbits. genomeA 3:e00482-15.

32. Shapiro LR, Andrade A, Scully ED, Rocha J, Paulson JN, Kolter R. 2018. Draft genome sequence of an Erwinia tracheiphila isolate from an infected muskmelon (Cucumis melo). Microbiology Resource Announcements 7:e01058-18.

33. Shapiro L. 2012. A to ZYMV guide to Erwinia tracheiphila infection: An ecological and molecular study. The Pennsylvania State University.

34. Shapiro LR, Paulson JN, Arnold BJ, Scully ED, Zhaxybayeva O, Pierce N, Rocha J, KlepacCeraj V, Holton K, Kolter R. 2018. An introduced crop plant is driving diversification of the virulent bacterial pathogen Erwinia tracheiphila. mBio 9:e01307-18.

35. Shapiro LR, Mauck KE. 2018. Chemically-mediated Interactions among cucurbits, insects and microbes, p 55-90. In Tabata J (ed), Chemical Ecology of Insects. CRC Press.

36. Smith EF. 1920. An introduction to bacterial diseases of plants. W.B. Saunders Company, Philadelphia.

37. Shapiro LR, Scully ED, Straub TJ, Park J, Stephenson AG, Beattie GA, Gleason ML, Kolter R, Coelho MC, Moraes CMD, Mescher MC, Zhaxybayeva O. 2016. Horizontal gene acquisitions, mobile element proliferation, and genome decay in the host-restricted plant pathogen Erwinia tracheiphila. Genome Biology and Evolution 8:649-664.

38. Moran NA, Plague GR. 2004. Genomic changes following host restriction in bacteria. Current Opinion in Genetics \& Development 14:627-633.

39. de Mackiewicz D, Gildow FE, Blua M, Fleischer SJ, Lukezic FL. 1998. Herbaceous weeds are not ecologically important reservoirs of Erwinia tracheiphila. Plant Disease 82:521529.

40. Shapiro L, Seidl-Adams I, De Moraes C, Stephenson A, Mescher M. 2014. Dynamics of short-and long-term association between a bacterial plant pathogen and its arthropod vector. Scientific Reports 4. 
41. Garcia-Salazar C, Gildow FE, Fleischer SJ, Cox-Foster D, Lukezic FL. 2000. ELISA versus immunolocalization to determine the association of Erwinia tracheiphila in Acalymma vittatum (Coleoptera: Chrysomelidae). Environmental Entomology 29:542-550.

42. Fleischer SJ, de Mackiewicz D, Gildow FE, Lukezic FL. 1999. Serological estimates of the seasonal dynamics of Erwinia tracheiphila in Acalymma vittata (Coleoptera: Chrysomelidae). Environmental Entomology 28:470-476.

43. Sasu M, Seidl-Adams I, Wall K, Winsor J, Stephenson A. 2010. Floral transmission of Erwinia tracheiphila by cucumber beetles in a wild Cucurbita pepo. Environmental Entomology 39:140-148.

44. Shapiro LR, Salvaudon L, Mauck KE, Pulido H, De Moraes CM, Stephenson AG, Mescher MC. 2013. Disease interactions in a shared host plant: effects of pre-existing viral infection on cucurbit plant defense responses and resistance to bacterial wilt disease. PLoS One 8:e77393.

45. Shapiro L, De Moraes CM, Stephenson AG, Mescher MC. 2012. Pathogen effects on vegetative and floral odours mediate vector attraction and host exposure in a complex pathosystem. Ecology Letters 15:1430-1438.

46. Sasu MA, Ferrari MJ, Du D, Winsor JA, Stephenson AG. 2009. Indirect costs of a nontarget pathogen mitigate the direct benefits of a virus-resistant transgene in wild Cucurbita. Proceedings of the National Academy of Sciences 106:19067-19071.

47. Marchler-Bauer A, Bo Y, Han L, He J, Lanczycki CJ, Lu S, Chitsaz F, Derbyshire MK, Geer RC, Gonzales NR. 2016. CDD/SPARCLE: functional classification of proteins via subfamily domain architectures. Nucleic Acids Research 45:D200-D203.

48. Lombard V, Golaconda Ramulu H, Drula E, Coutinho PM, Henrissat B. 2013. The carbohydrate-active enzymes database (CAZy) in 2013. Nucleic Acids Research 42:D490D495.

49. Aziz R, Bartels D, Best A, DeJongh M, Disz T, Edwards R, Formsma K, Gerdes S, Glass E, Kubal M, Meyer F, Olsen G, Olson R, Osterman A, Overbeek R, McNeil L, Paarmann D, Paczian T, Parrello B, Pusch G, Reich C, Stevens R, Vassieva O, Vonstein V, Wilke A, Zagnitko O. 2008. The RAST Server: Rapid Annotations using Subsystems Technology. BMC Genomics 9:75.

50. Armenteros JJA, Tsirigos KD, Sønderby CK, Petersen TN, Winther O, Brunak S, von Heijne G, Nielsen H. 2019. SignalP 5.0 improves signal peptide predictions using deep neural networks. Nature Biotechnology 37:420-423.

51. Thomas CM, Nielsen KM. 2005. Mechanisms of, and barriers to, horizontal gene transfer between bacteria. Nature Reviews Microbiology 3:711.

52. Ochman H, Lawrence JG, Groisman EA. 2000. Lateral gene transfer and the nature of bacterial innovation. Nature 405:299-304.

53. Zhaxybayeva O, Doolittle WF. 2011. Lateral gene transfer. Current Biology 21:R242R246.

54. Halpern M, Fridman S, Aizenberg-Gershtein Y, Izhaki I. 2013. Transfer of Pseudomonas flectens Johnson 1956 to Phaseolibacter gen. nov., in the family Enterobacteriaceae, as Phaseolibacter flectens gen. nov., comb. nov. International Journal of Systematic and Evolutionary Microbiology 63:268-273. 
898

899

900

901

902

903

904

905

906

907

908

909

910

911

912

913

914

915

916

917

918

919

920

921

922

923

924

925

926

927

928

929

930

931

932

933

934

935

936

937

938

939

940

55. Mensi I, Vernerey M-S, Gargani D, Nicole M, Rott P. 2014. Breaking dogmas: the plant vascular pathogen Xanthomonas albilineans is able to invade non-vascular tissues despite its reduced genome. Royal Society Open Biology 4:130116.

56. Franklin NC. 1978. Genetic fusions for operon analysis. Annual Review of Genetics 12:193-221.

57. Vrisman CM, Deblais L, Rajashekara G, Miller SA. 2016. Differential colonization dynamics of cucurbit hosts by Erwinia tracheiphila. Phytopathology 106:684-692.

58. Cosgrove DJ. 2016. Catalysts of plant cell wall loosening. F1000Research 5.

59. Malinovsky FG, Fangel JU, Willats WG. 2014. The role of the cell wall in plant immunity. Frontiers in Plant Science 5:178.

60. Bahar O, Goffer T, Burdman S. 2009. Type IV pili are required for virulence, twitching motility, and biofilm formation of Acidovorax avenae subsp. citrulli. Molecular PlantMicrobe Interactions 22:909-920.

61. Burdman S, Bahar O, Parker JK, De La Fuente L. 2011. Involvement of type IV pili in pathogenicity of plant pathogenic bacteria. Genes 2:706-735.

62. Cursino L, Galvani CD, Athinuwat D, Zaini PA, Li Y, De La Fuente L, Hoch HC, Burr TJ, Mowery P. 2011. Identification of an operon, Pil-Chp, that controls twitching motility and virulence in Xylella fastidiosa. Molecular plant-microbe interactions 24:1198-1206.

63. Bahar O, Levi N, Burdman S. 2011. The cucurbit pathogenic bacterium Acidovorax citrulli requires a polar flagellum for full virulence before and after host-tissue penetration. Molecular Plant-Microbe Interactions 24:1040-1050.

64. Ewald PW. 1993. Evolution of infectious disease. Oxford University Press.

65. Mackinnon M, Read AF. 2004. Virulence in malaria: an evolutionary viewpoint. Philosophical Transactions of the Royal Society B: Biological Sciences 359:965-986.

66. Hinnebusch BJ, Joseph B, Perry RD, Schwan TG. 1996. Role of the Yersinia pestis hemin storage (hms) locus in the transmission of plague by fleas. Science 273:367.

67. Yao C, Zehnder, G., Bauske, E., Kloepper, J. 1996. Relationship between cucumber beetle (Coleoptera: Chrysomelidae) density and incidence of bacterial wilt of cucurbits. Journal of Economic Entomology 89:510-514.

68. Pasek S, Risler J-L, Brézellec P. 2006. Gene fusion/fission is a major contributor to evolution of multi-domain bacterial proteins. Bioinformatics 22:1418-1423.

69. Yang S BP. 2009. The evolutionary history of protein domains viewed by species phylogeny. PLoS ONE 4:e8378.

70. Boutilier MS, Lee J, Chambers V, Venkatesh V, Karnik R. 2014. Water filtration using plant xylem. PLoS One 9:e89934.

71. Pérez-Donoso AG, Sun Q, Roper MC, Greve LC, Kirkpatrick B, Labavitch JM. 2010. Cell wall-degrading enzymes enlarge the pore size of intervessel pit membranes in healthy and Xylella fastidiosa-infected grapevines. Plant Physiology 152:1748-1759.

72. Yadeta K, Thomma B. 2013. The xylem as battleground for plant hosts and vascular wilt pathogens. Frontiers in Plant Science 4.

73. Secchi F, Pagliarani C, Zwieniecki MA. 2017. The functional role of xylem parenchyma cells and aquaporins during recovery from severe water stress. Plant, Cell \& Environment 40:858-871. 
941 74. Christman MA, Sperry JS. 2010. Single-vessel flow measurements indicate scalariform

942

943

944

945

946

947

948

949

950

951

952

953

954

955

956

957

958

959

960

961

962

963

964

965

966

967

968

969

970

971

972

973

974

975

976

977

978

979

980

981

982

983 perforation plates confer higher flow resistance than previously estimated. Plant, Cell \& Environment 33:431-443.

75. Roper MC. 2011. Pantoea stewartii subsp. stewartii: lessons learned from a xylemdwelling pathogen of sweet corn. Molecular Plant Pathology 12:628-637.

76. Foley JA, DeFries R, Asner GP, Barford C, Bonan G, Carpenter SR, Chapin FS, Coe MT, Daily GC, Gibbs HK. 2005. Global consequences of land use. Science 309:570-574.

77. Nasaruddin AS, Babler BN, Perna NT, Glasner JD, Charkowski AO. 2019. First report of Dickeya dianthicola causing blackleg on potato in Texas. Plant Disease.

78. Cai W, Srivastava S, Stulberg M, Nakhla M, Rascoe J. 2018. Draft genome sequences of two Dickeya dianthicola isolates from potato. Genome announcements 6:e00115-18.

79. Ma X, Schloop A, Swingle B, Perry KL. 2018. Pectobacterium and Dickeya responsible for potato blackleg disease in New York State in 2016. Plant Disease 102:1834-1840.

80. Dean R, Van Kan JA, Pretorius ZA, Hammond-Kosack KE, Di Pietro A, Spanu PD, Rudd JJ, Dickman M, Kahmann R, Ellis J. 2012. The 'Top 10' fungal pathogens in molecular plant pathology. Molecular Plant Pathology 13:414-430.

81. Mansfield J, Genin S, Magori S, Citovsky V, Sriariyanum M, Ronald P, Dow M, Verdier V, Beer SV, Machado MA. 2012. Top 10 plant pathogenic bacteria in molecular plant pathology. Molecular Plant Pathology 13:614-629.

82. Bae C, Han SW, Song Y-R, Kim B-Y, Lee H-J, Lee J-M, Yeam I, Heu S, Oh C-S. 2015. Infection processes of xylem-colonizing pathogenic bacteria: possible explanations for the scarcity of qualitative disease resistance genes against them in crops. Theoretical and Applied Genetics 128:1219-1229.

83. Agrios. 2005. Plant pathology, http://doc18.rupdfbook.com/plant-pathology-fifth-editionby-george-n-agrios-PDFs-179089.pdf.

84. Metcalf R, Lampman R. 1989. The chemical ecology of Diabroticites and Cucurbitaceae. Experientia 45:240-247.

85. Joseph JG, Douglas WT, Edward GR, Anthony IC. 2008. Molecular phylogeny of rootworms and related galerucine beetles (Coleoptera: Chrysomelidae). Zoologica Scripta 37:195-222.

86. Rand FV, Cash LC. 1920. Some insect relations of Bacillus tracheiphilus Erw. Sm. Phytopathology 10:133-140.

87. Garcia-Salazar C, Gildow FE, Fleischer SJ, Cox-Foster D, Lukezic FL. 2000. Alimentary canal of adult Acalymma vittata (Coleoptera: Chrysomelidae): morphology and potential role in survival of Erwinia tracheiphila (Enterobacteriaceae). Canadian Journal of Entomology 132:1-13.

88. Roberts DC, Fleischer SJ, Sakamoto JM, Rasgon JL. 2018. Potential biological control of Erwinia tracheiphila by internal alimentary canal interactions in Acalymma vittatum with Pseudomonas fluorescens. Journal of Applied Microbiology 125:1137-1146.

89. Rand FV, Enlows EMA. 1916. Transmission and control of bacterial wilt of cucurbits. Journal of Agricultural Research 6:7-434.

90. Rand FV. 1915. Dissemination of bacterial wilt of cucurbits. Journal of Agricultural Research 5:257-260. 
984 91. Whitaker TW, Bemis W. 1975. Origin and evolution of the cultivated Cucurbita. Bulletin

985

986

987

988

989

990

991

992

993

994

995

996

997

998

999

1000

1001

1002

1003

1004

1005

1006

1007

1008

1009

1010

1011

1012

1013

1014

1015

1016

1017

1018

1019

1020

1021

1022

1023

1024

1025

1026

of the Torrey Botanical Club:362-368.

92. Nee M. 1990. The domestication of Cucurbita (Cucurbitaceae). Economic Botany 44:5668.

93. Schaefer H, Heibl C, Renner SS. 2009. Gourds afloat: a dated phylogeny reveals an Asian origin of the gourd family (Cucurbitaceae) and numerous oversea dispersal events. Proceedings of the Royal Society of London B: Biological Sciences 276:843-851.

94. Sebastian P, Schaefer H, Telford IRH, Renner SS. 2010. Cucumber (Cucumis sativus) and melon (C. melo) have numerous wild relatives in Asia and Australia, and the sister species of melon is from Australia. Proceedings of the National Academy of Sciences 107:14269-14273.

95. L.A. N, Trieu DA. 2011. Fusion gardens: Native North America and the Columbian Exchange. In Smith B (ed), Subsistence Economies of Indigenous North American Societies: A Handbook. Rowman and Littlefield Publishing Group, Lanham, MD.

96. Bisognin DA. 2002. Origin and evolution of cultivated cucurbits. Ciência Rural 32:715723.

97. Datsenko KA, Wanner BL. 2000. One-step inactivation of chromosomal genes in Escherichia coli K-12 using PCR products. Proceedings of the National Academy of Sciences 97:6640-6645.

98. Altschul SF, Gish W, Miller W, Myers EW, Lipman DJ. 1990. Basic local alignment search tool. Journal of Molecular Biology 215:403-410.

99. Katoh K, Misawa K, Kuma Ki, Miyata T. 2002. MAFFT: a novel method for rapid multiple sequence alignment based on fast Fourier transform. Nucleic Acids Research 30:30593066.

100. Capella-Gutiérrez S, Silla-Martínez JM, Gabaldón T. 2009. trimAl: a tool for automated alignment trimming in large-scale phylogenetic analyses. Bioinformatics 25:1972-1973.

101. Abascal F, Zardoya R, Posada D. 2005. ProtTest: selection of best-fit models of protein evolution. Bioinformatics 21:2104-2105.

102. Stamatakis A. 2006. RAxML-VI-HPC: maximum likelihood-based phylogenetic analyses with thousands of taxa and mixed models. Bioinformatics 22:2688-2690.

103. Miller MA, Pfeiffer W, Schwartz T. Creating the CIPRES Science Gateway for inference of large phylogenetic trees, p 1-8. In (ed),

104. Sukumaran J, Holder MT. 2010. DendroPy: A Python library for phylogenetic computing. Bioinformatics 26:1569-1571.

105. Team RC. 2015. R: A language and environment for statistical computing. R Foundation of Statistical Computing Vienna, Austria.

106. Yu G, Smith DK, Zhu H, Guan Y, Lam TTY. 2017. ggtree: an R package for visualization and annotation of phylogenetic trees with their covariates and other associated data. Methods in Ecology and Evolution 8:28-36.

107. Guy L, Kultima JR, Andersson SG. 2010. genoPlotR: comparative gene and genome visualization in R. Bioinformatics 26:2334-2335.

108. Philippe N, Alcaraz J-P, Coursange E, Geiselmann J, Schneider D. 2004. Improvement of pCVD442, a suicide plasmid for gene allele exchange in bacteria. Plasmid 51:246-255. 
bioRxiv preprint doi: https://doi.org/10.1101/681643; this version posted July 2, 2019. The copyright holder for this preprint (which was not certified by peer review) is the author/funder, who has granted bioRxiv a license to display the preprint in perpetuity. It is made available under aCC-BY-NC-ND 4.0 International license.

1027 109. Lagendijk EL, Validov S, Lamers GE, De Weert S, Bloemberg GV. 2010. Genetic tools for 1028 tagging Gram-negative bacteria with mCherry for visualization in vitro and in natural habitats, biofilm and pathogenicity studies. FEMS Microbiology Letters 305:81-90.

1030 110. Machin D, Cheung YB, Parmar M. 2006. Survival analysis: a practical approach. John 1031 Wiley \& Sons. 
A.

bioRxiv preprint doi: https://doi org/10.1101/681643; this version posted July 2, 2019. The copyright holder for this preprint (which was not certified by peer review) is the author/funder, who has granted bioRxiv a license to display the preprint in perpetuity. It is made available under aCC-BY-NC-ND 4.0 International license.

B.

Taxonomic Group Enterobacteria Xanthomonadales Other y-proteobacteria

B-Proteobacteria

Myxobacteria Actinobacteria Bacteroidetes

Nematoda Firmicutes

\section{Pectobacterium wasabiae} Pectobacterium parmentiere Pectobacterium peruviense
Pectobacterium atrosepticum Pectobacterium punjabense 98 Pectobacterium polaris
${ }_{85}$ Pectobacterium carotovorum Brennaria salicis
Erwinia sp. AG740 100 Erwinia sp. AG740 Dickeya dadantii Dickeya fangzhongdai 99 Dickeya chrysanthem Dickeya solani onsdalea quercina 100 Lon Lonsdalea iberica 100 Lonsdalea dianthicola 100 Pantoea stewartii ${ }^{82} 98$ Bacillus halotolerans Bacillus subtilis 100 Bacillus cellulasensis Paenibacillus polysaccharolyticus Pa 2 aenibachus $\mathrm{xy}$ anexed Xanthomonas cannabis Xanthomonas melonis Xanthomonas populi Xanthomonas bromi ${ }_{98}$ Xanthomonas phaseoli Xanthomonas citri Xylella taiwanensis
Xylella fastidiosa

- 100 Ralstonia pseudosolanacearum Archangium gephyra

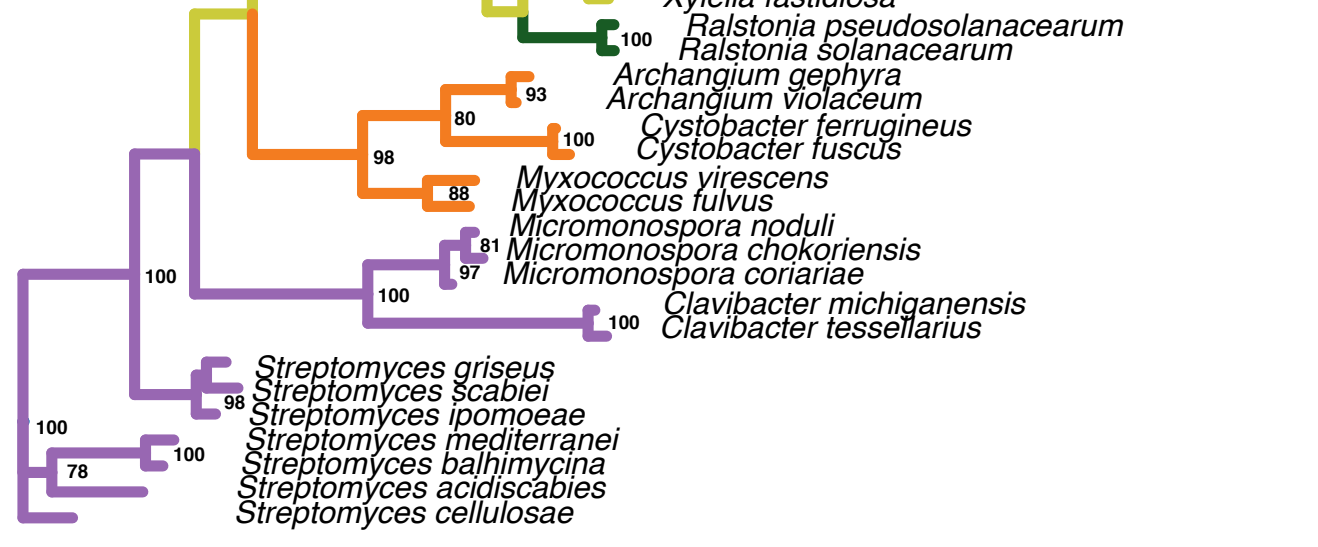

C.

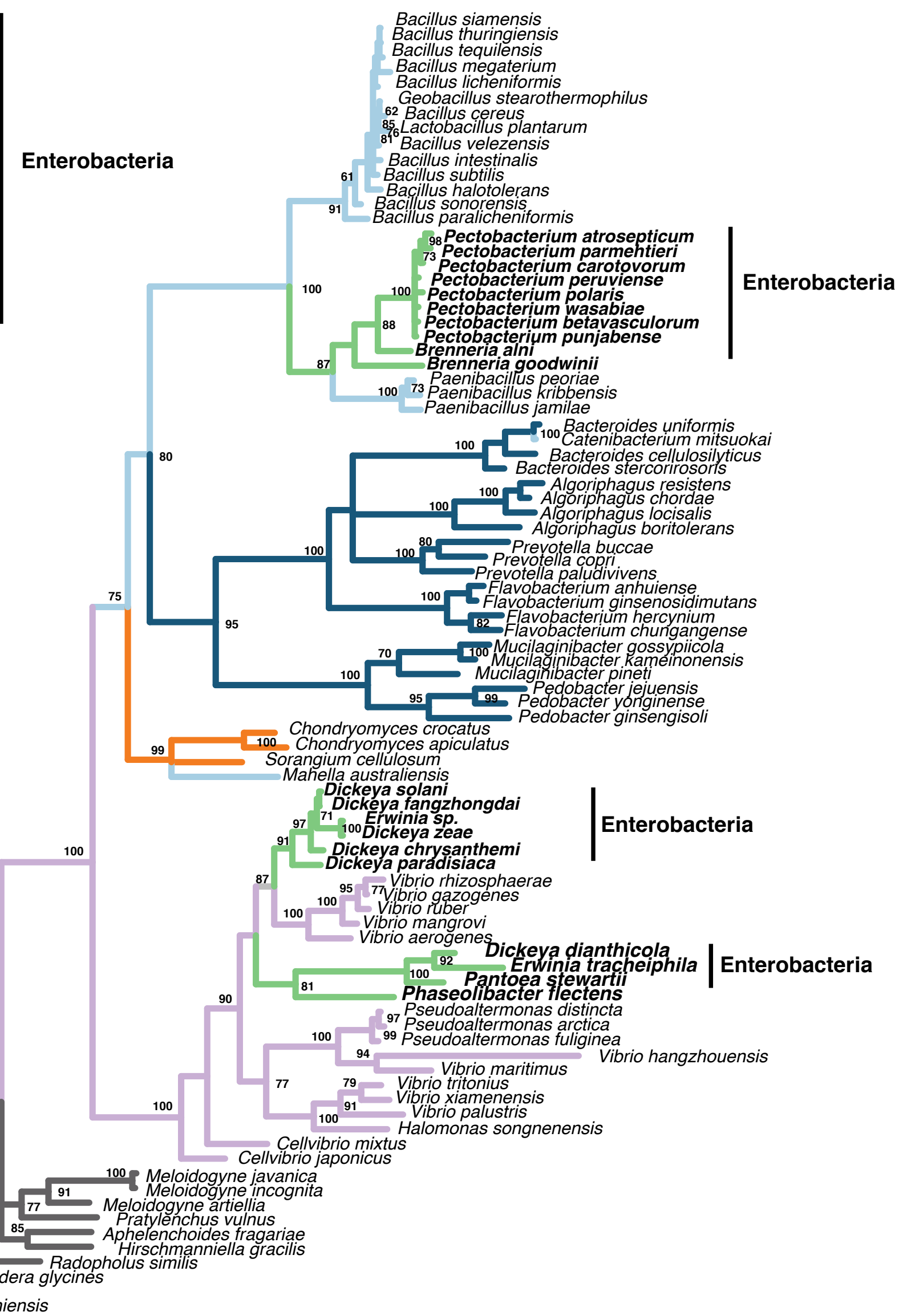


Signal Peptide

Expansin

GH5 (endo-1-4-beta-xylanase A)

GH5 (beta-D-glucosidase BgIC)

GH5

Carbohydrate binding module II

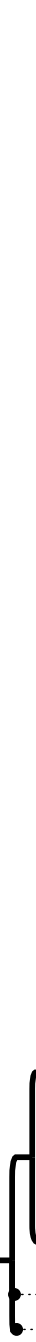

$0.3 \mathrm{aa} / \mathrm{site}$

Tree scale
Pantoea ananatis

Pantoea stewartii

Erwinia tracheiphila

Pantoea septica

Pantoea rodasii

Lonsdalea quercina

Lonsdalea iberica

Lonsdalea britannica

Brennaria goodwinii

Pectobacterium carotovorum

Pectobacterium wasabiae

Pectobacterium betavasculorum

Pectobacterium peruviense

Brennaria rubrifaciens

Brennaria salicis

Dickeya solani

Dickeya zeae

Dickeya dianthicola

Xanthomonas translucens

Xanthomonas oryzae

Xanthomonas arboricola

Xanthomonas phaseoli

Xanthomonas campestris

Xanthomonas citri

Xylella fastidiosa

Xylella taiwanensis

Xanthomonas sacchari

Xanthomonas albilineans

Acidovorax radicis

Acidovorax avenae

Acidovorax citrulli

Ralstonia insidiosa

Ralstonia pickettii

Ralstonia pseudosolanacearum

Ralstonia solanacearum

Myxococcus fulvus

Myxococcus virescens

Clavibacter michiganensis

Streptomyces scabiei

Streptomyces cellulosae

Streptomyces griseus

Streptomyces ipomoeae

Paenibacillus xylanexedens

Bacillus subtilis

Bacillus halotolerans

Bacillus licheniformis

Bacillus glycinifermentans

Bacillus cellulasensis

Bacillus pumilus
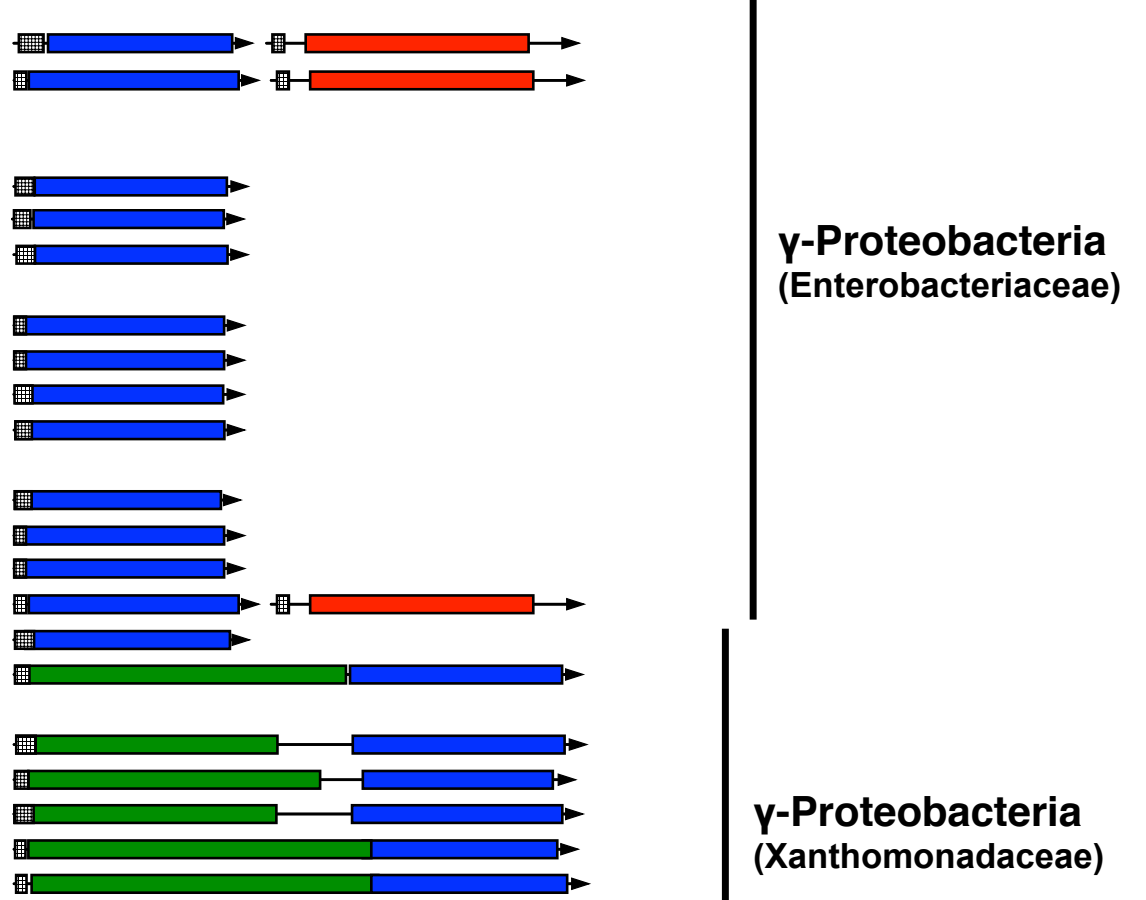

谓—
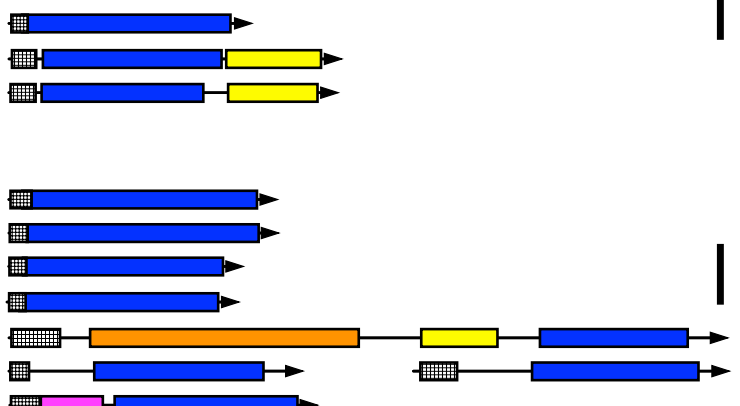

典口 $\square$
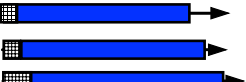

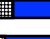

贯

贯

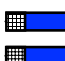

西次

빔

100 aa

Coding sequence scale
B-Proteobacteria

y-Proteobacteria

(Xanthomonadaceae)

\section{$\delta$-Proteobacteria}

Actinobacteria

Firmicutes 

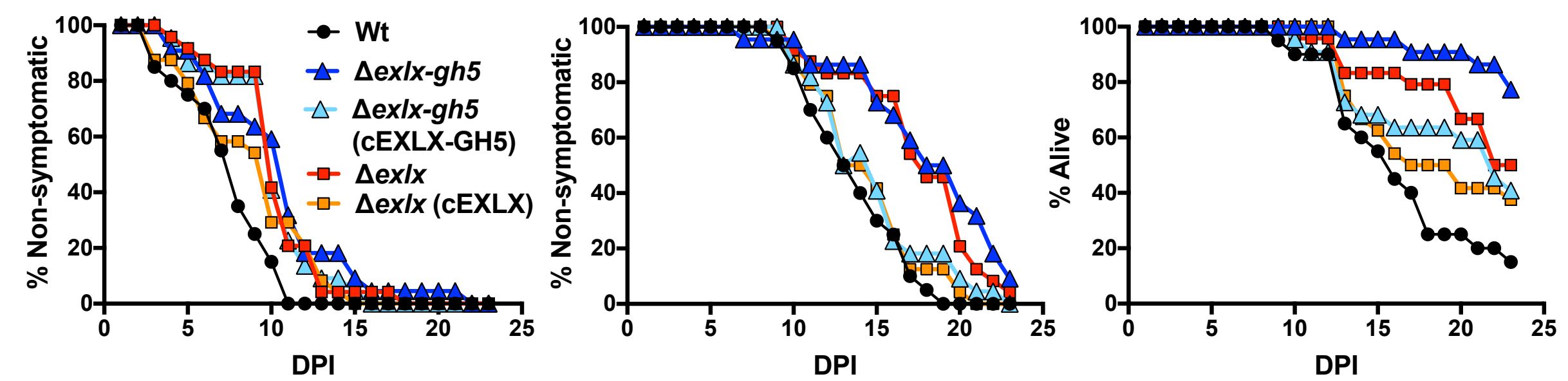

B)
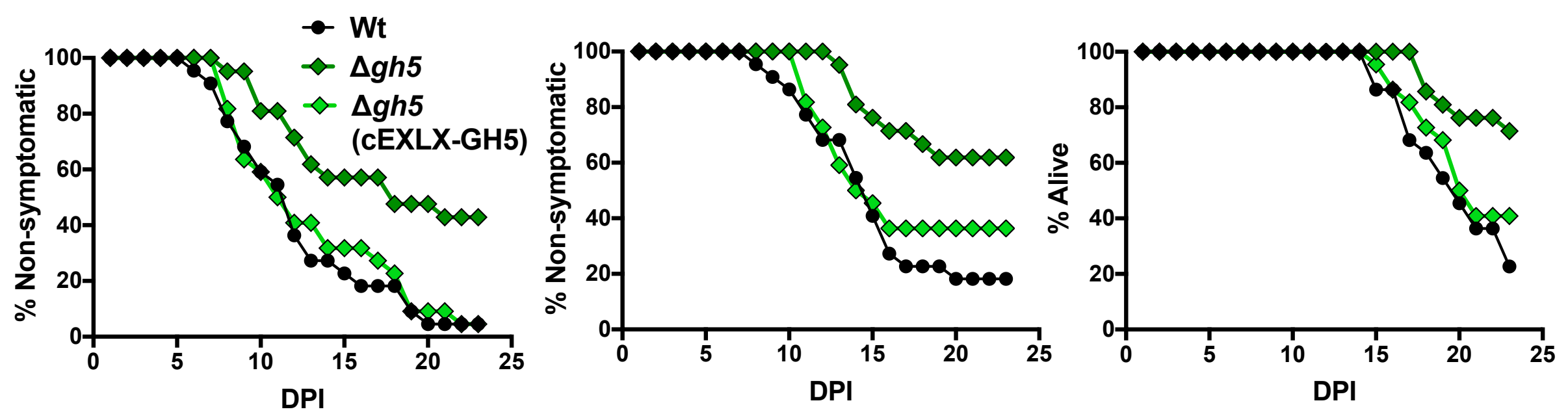

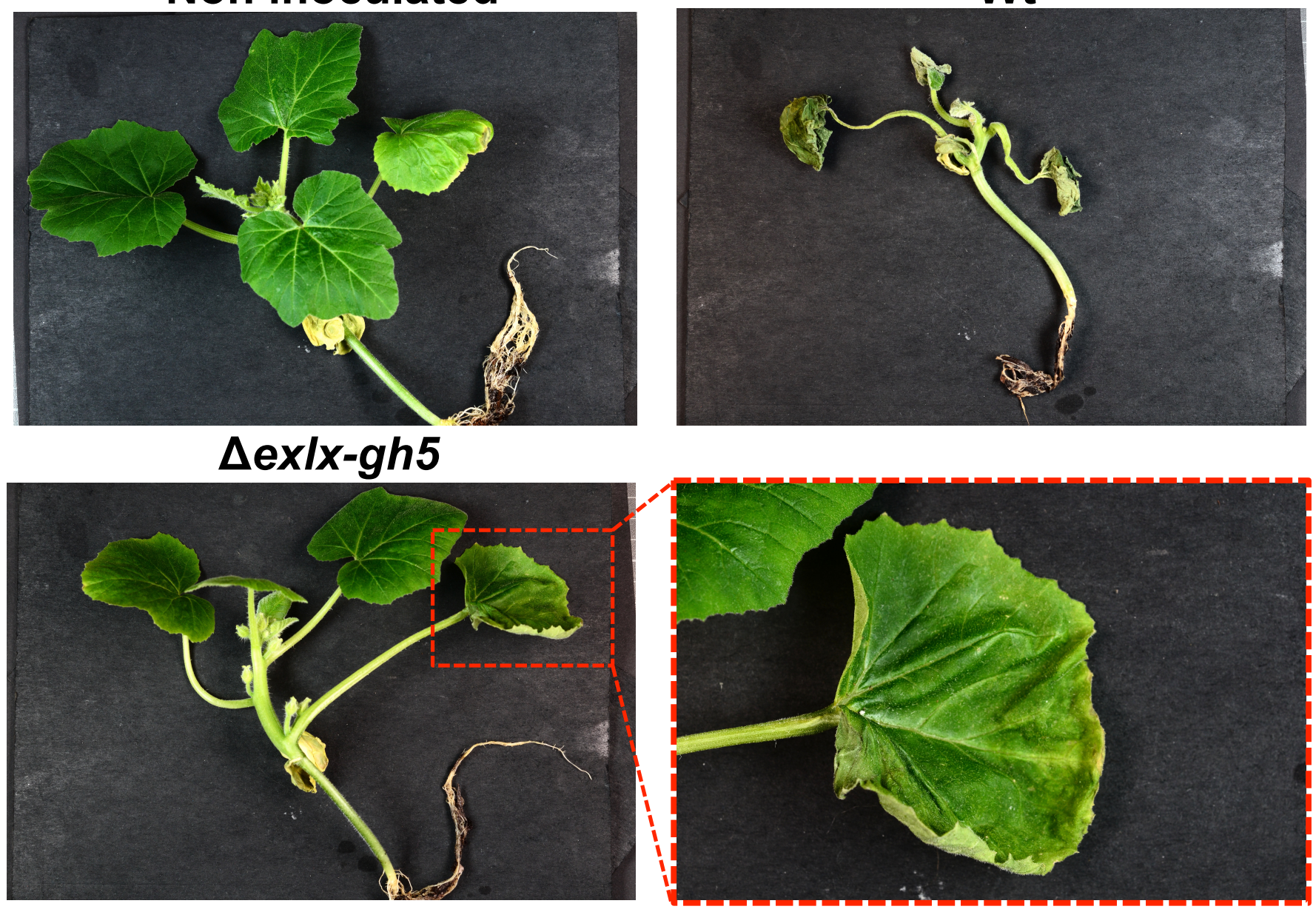

D)

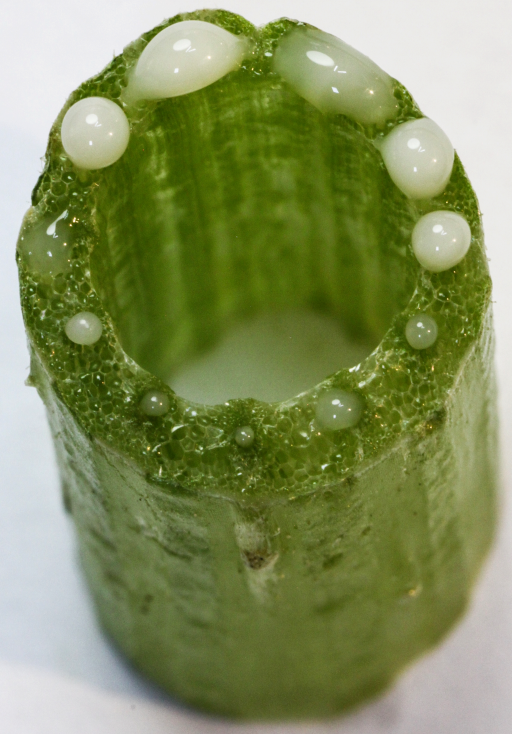

E)

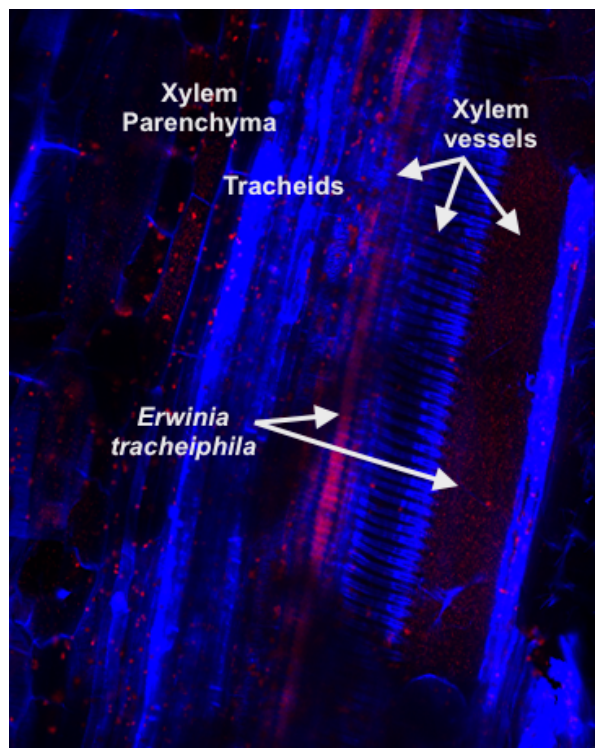




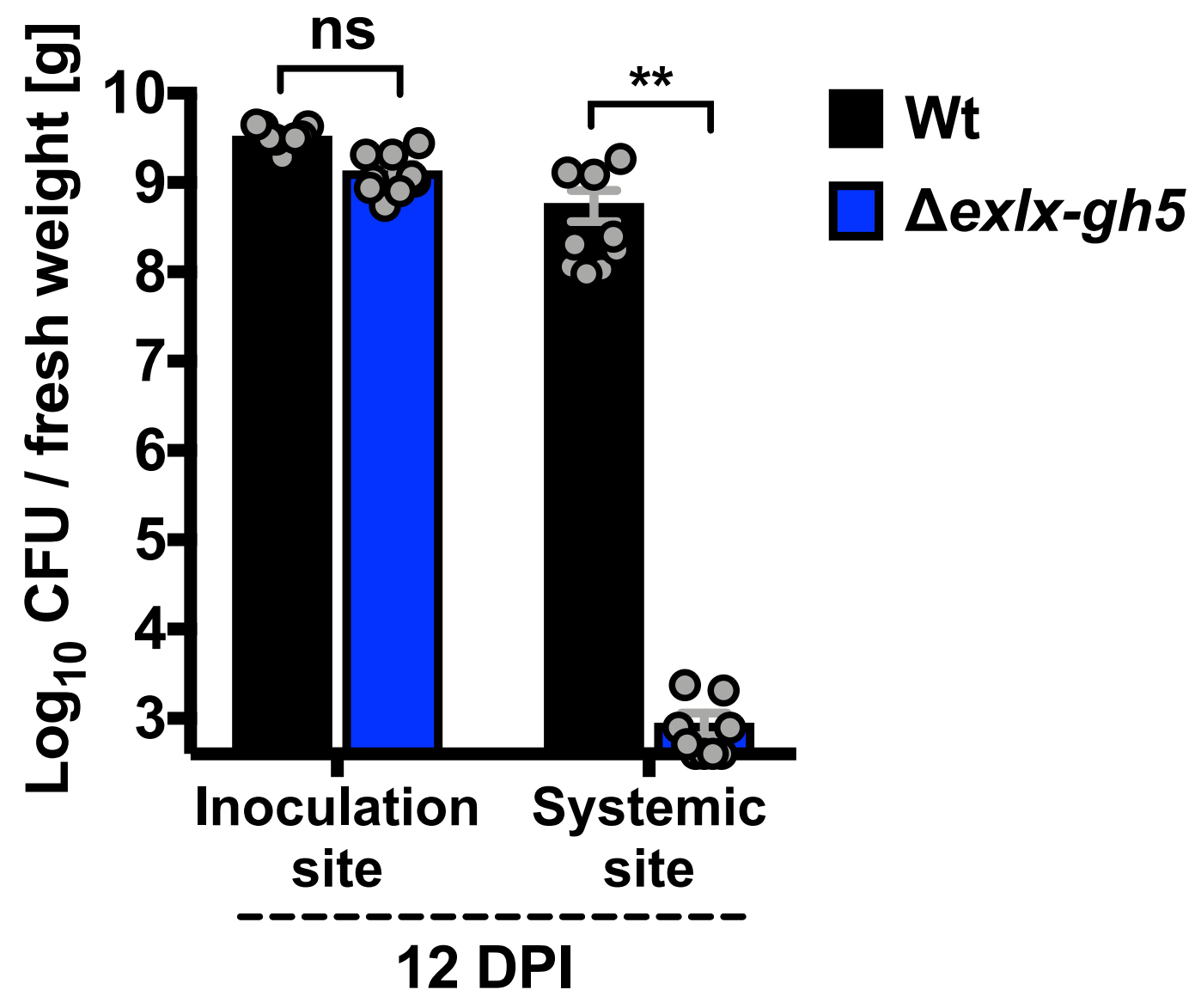




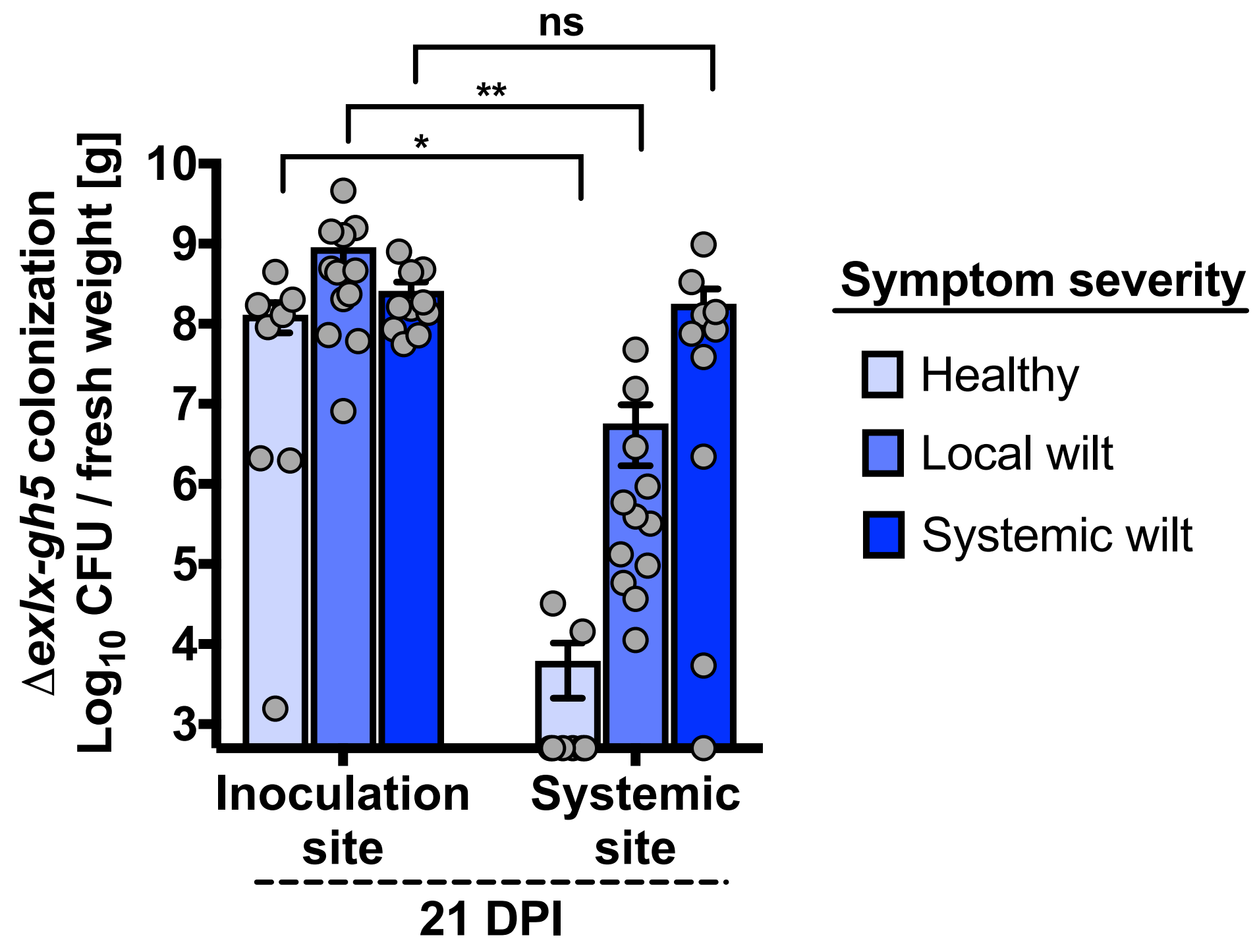


Wilt in inoculated leaf

Wilt in second systemic leaf

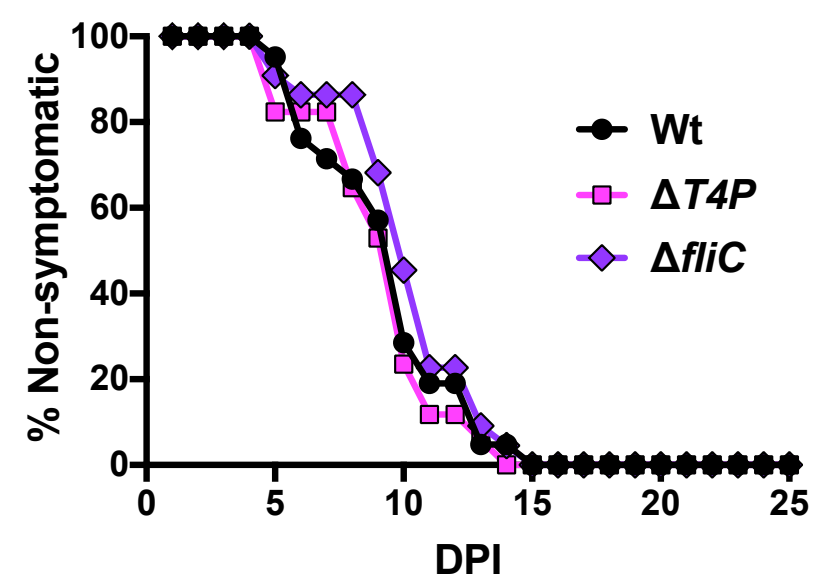

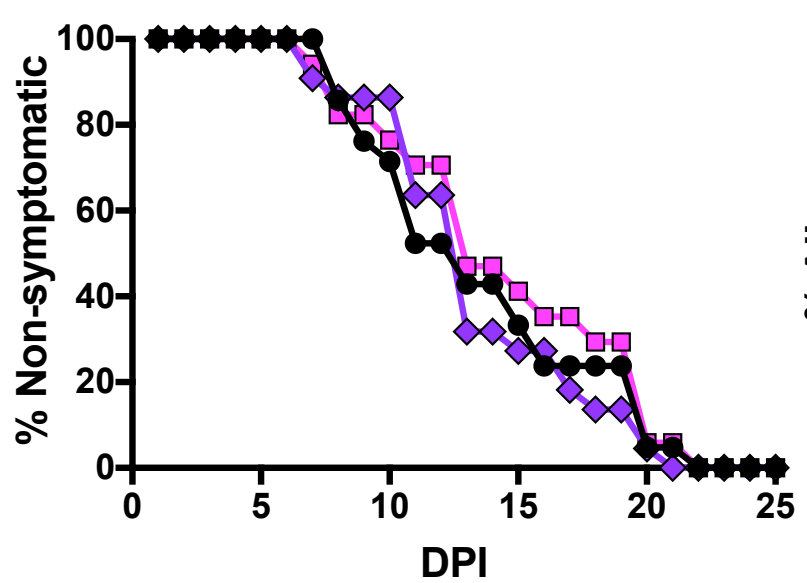

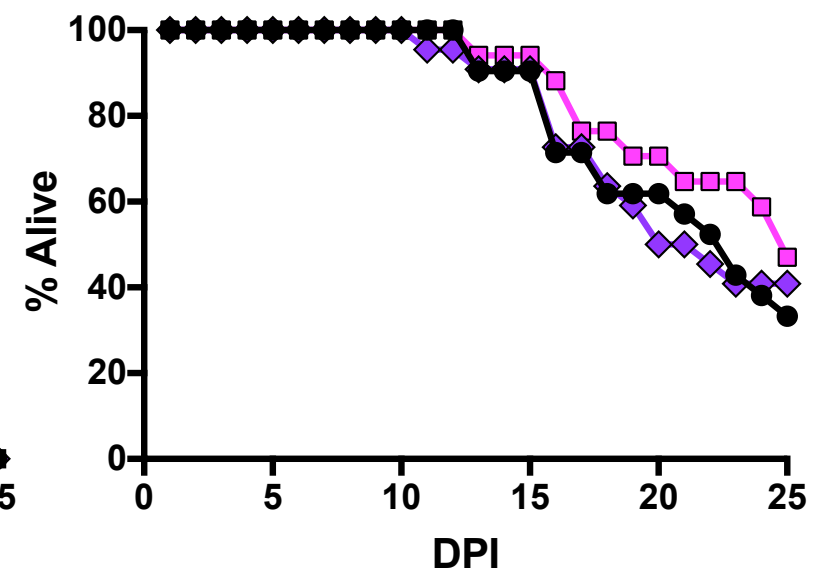


Single inoculations

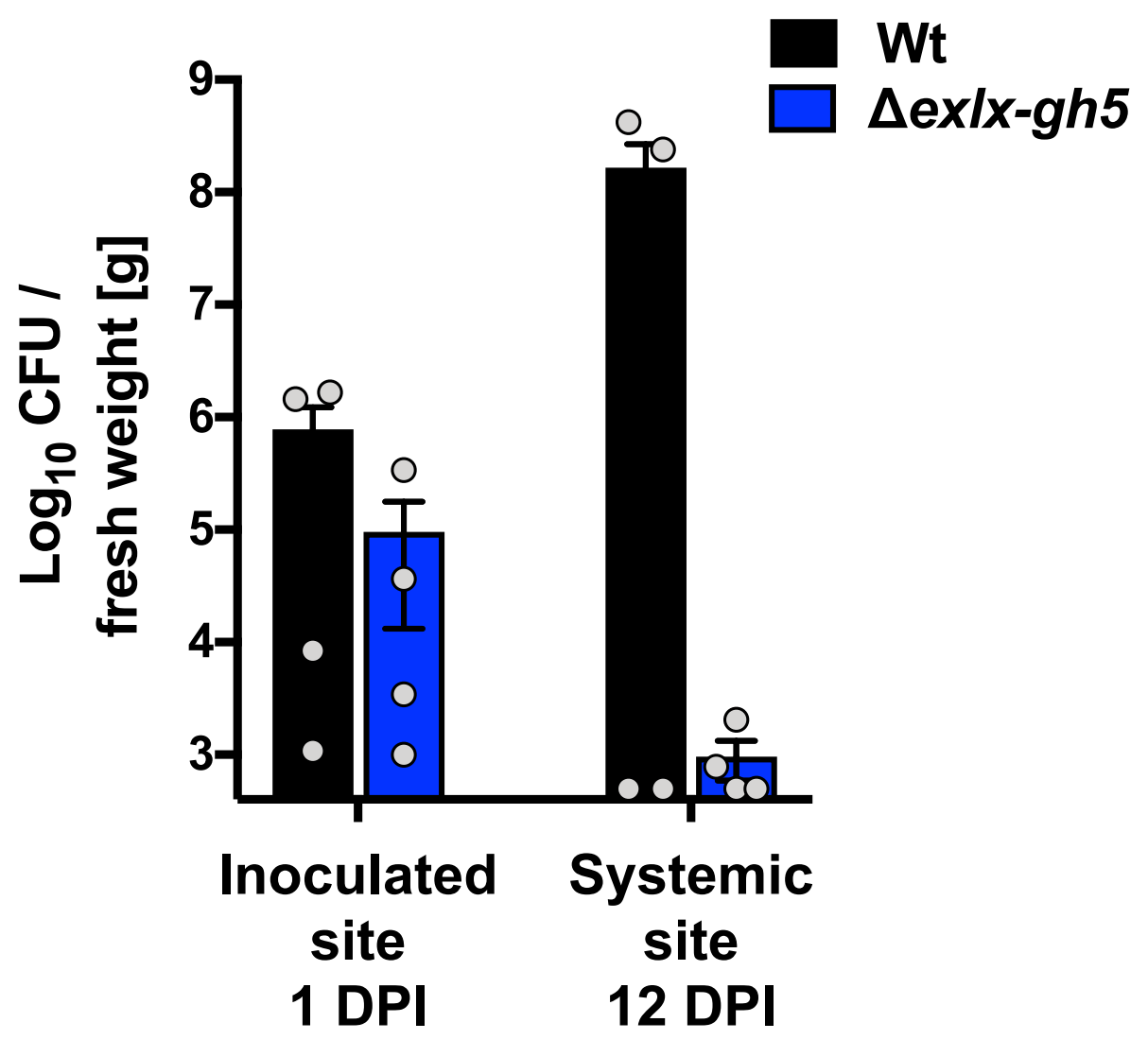

Co-inoculation

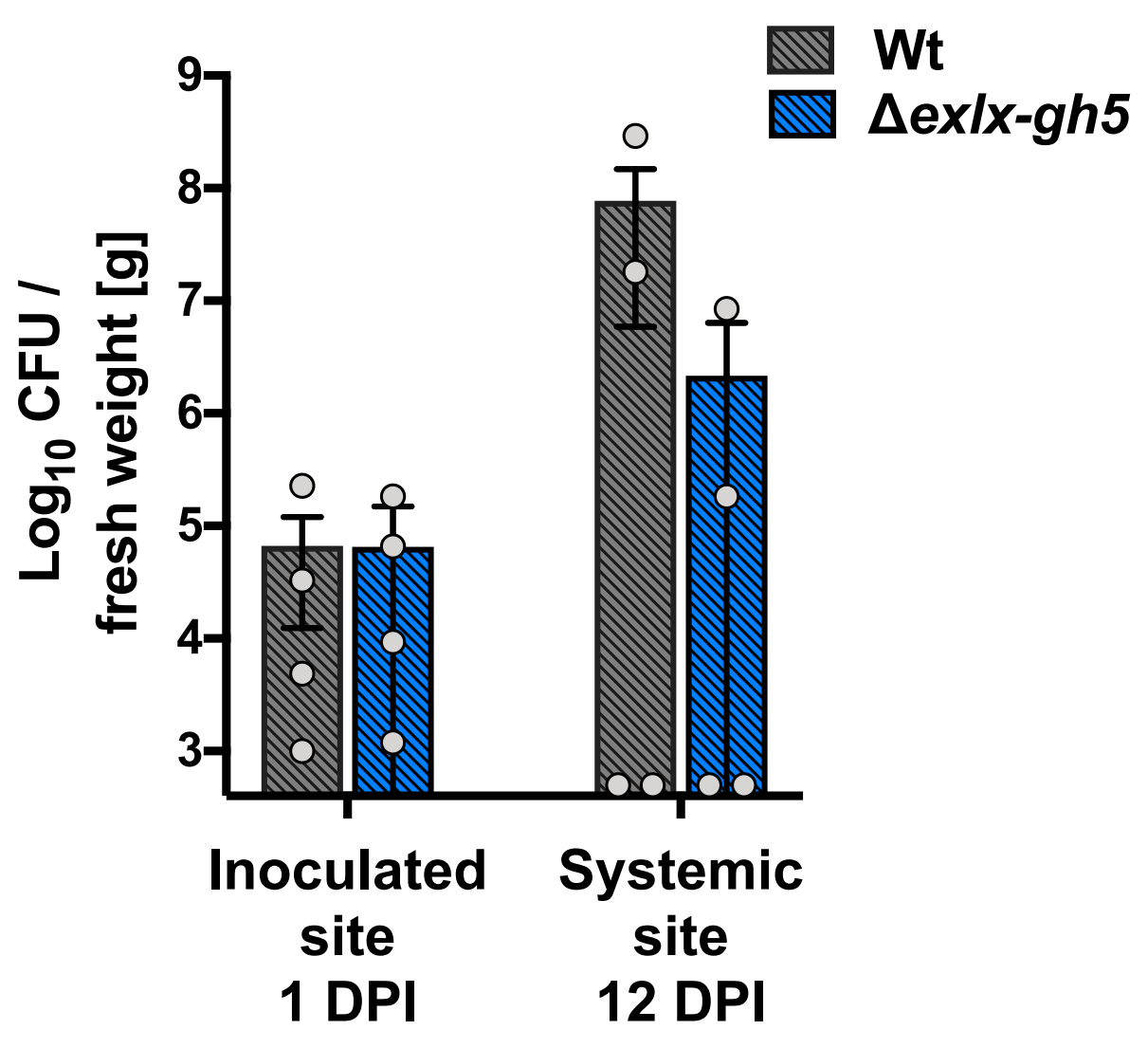




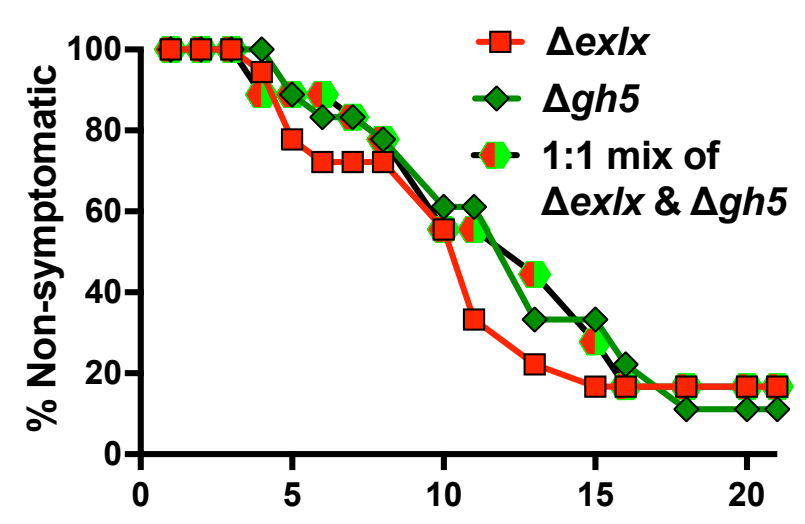

DPI

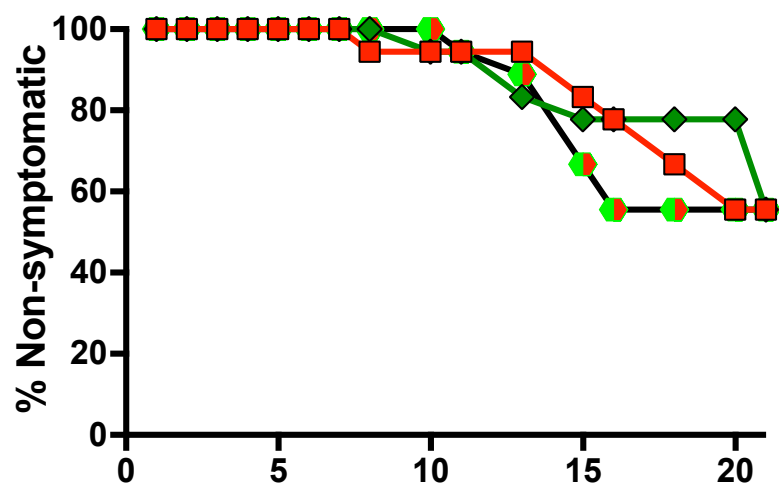

DPI

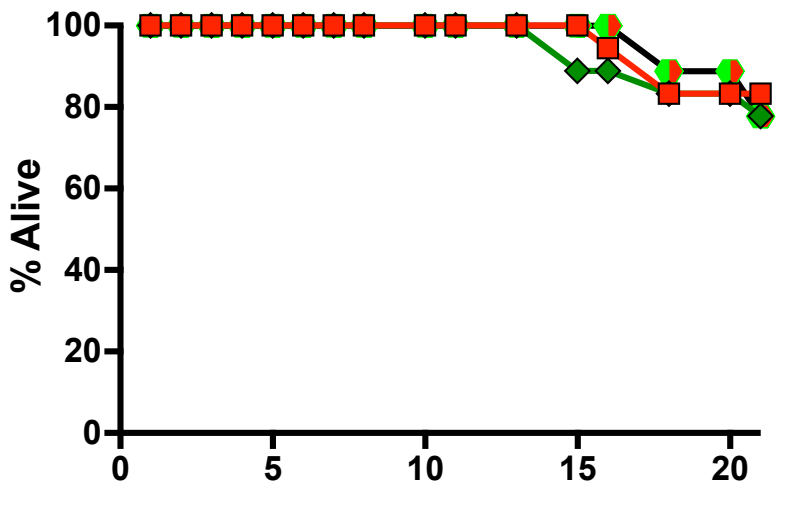

DPI 